\title{
EFFECTS OF THE CURING TEMPERATURE ON THE PERFORMANCE OF GLASS FIBRE REINFORCED BASIC MAGNESIUM SULFATE CEMENT
}

\author{
PANPAN LIU*, ${ }^{\#}$ CHENGYOU WU*, KEJIE LUO*, CONG CHEN*, YUANJI CHEN*, \\ HUIFANG ZHANG**, HONGFA YU*** \\ *School of Civil Engineering, Qinghai University, Xining 810016, PR China \\ **Qinghai Institute of Salt Lakes, Chinese Academy of Sciences, Xining 810008, PR China. \\ ***Department of Civil Engineering, Nanjing University of Aeronautics and Astronautics, Nanjing 210016,PR China \\ \#E-mail: wuchengyou86@163.com
}

Submitted July 12, 2018; accepted September 28,2018

\begin{abstract}
Keywords: Basic magnesium sulphate cement, Curing temperature, Hydration phase, Compressive strength, Flexural strength
In order to investigate the effect of different curing conditions on the properties of glass fibre reinforced basic magnesium sulfate cement (GRBMS), the compressive strength, flexural strength, and water resistance of the GRBMS were determined for five curing modes at $20^{\circ} \mathrm{C}, 50^{\circ} \mathrm{C}$, and $80^{\circ} \mathrm{C}$. The phase composition of the hydrated product was analysed by X-ray diffraction and the microstructure was analysed using scanning electron microscopy (SEM) images. The results show that the curing temperature in the early stage of curing has a significant effect on the type of the primary reaction products. The main strength phase, resulting from the curing temperatures of $20^{\circ} \mathrm{C}$ and $50^{\circ} \mathrm{C}$, is the 517 needle-like phase, whereas the curing temperature of $80^{\circ} \mathrm{C}$ produces the 513 sheet-like phase. The strength phase of the cement-based material is the 517 phase when cured at $20^{\circ} \mathrm{C}$ for 1 day; after curing at $80^{\circ} \mathrm{C}$ for 3 days, the 517 phase loses water and changes into the 513 phase, changing the morphology. The pre-curing specimens have the lowest water resistance at $80{ }^{\circ} \mathrm{C}$, indicating that the water resistance of the GRBMS sample is affected by both the curing temperature and the curing mode.
\end{abstract}

\section{INTRODUCTION}

Magnesium oxysulfate (MOS) cement is a nonhydraulic cementitious material. It is formed by mixing a suitable proportion of magnesium oxide $(\mathrm{MgO})$ powder (usually calcined at $700-900{ }^{\circ} \mathrm{C}$ ) with a concentrated magnesium sulfate $\left(\mathrm{MgSO}_{4}\right)$ solution [1] It was determined that the magnesium hydroxide sulfate $\left[\mathrm{xMg}(\mathrm{OH})_{2} \cdot \mathrm{yMgSO}_{4} \cdot \mathrm{zH}_{2} \mathrm{O}\right]$ phase was discovered as the main component of MOS cement [2]. MOS cement hardens rapidly and has excellent fire performance, low thermal conductivity, good abrasion resistance, and good chemical resistance [3-5]. Therefore, it can be used as a fire-proof material [6], reinforcement additive [7], and building material. However, its hydration products are not stable; therefore, the mechanical strength of MOS cement is very low and it has limited use in practical engineering applications, which greatly restricts its utilisation. If the mechanical strength of MOS cement could be improved, it would be an excellent cementing material and may replace magnesium oxychloride (MOC) cement in some cases, especially at higher temperatures [8]. The strength of MOS cement depends on the type and relative content of the crystalline phases in the cement. Cole [9] conducted one of the earliest studies on the effect of temperature on the hydration product composition of MOC cement and determined the composition of the stable crystalline phase in the system and its temperature range. The results showed that at temperatures of less than $100^{\circ} \mathrm{C}$, two stable MOC hydrate crystal phases existed, namely $5 \mathrm{Mg}(\mathrm{OH})_{2} \cdot \mathrm{MgCl}_{2} \cdot 8 \mathrm{H}_{2} \mathrm{O}$ (the 518 phase) and $3 \mathrm{Mg}(\mathrm{OH})_{2} \cdot \mathrm{MgCl}_{2} \cdot 8 \mathrm{H}_{2} \mathrm{O}$ (the 318 phase). Similarly, when the temperature was greater than $100{ }^{\circ} \mathrm{C}$, two kinds of stable crystal phases existed, namely $2 \mathrm{Mg}(\mathrm{OH})_{2} \cdot \mathrm{MgCl}_{2} \cdot 4 \mathrm{H}_{2} \mathrm{O}$ (the 214 phase) and $9 \mathrm{Mg}(\mathrm{OH})_{2} \cdot \mathrm{MgCl}_{2} \cdot 5 \mathrm{H}_{2} \mathrm{O}$ (the 915 phase). However, in MOS cement, Demediuk and Cole [10] identified four major crystalline phases in the $\mathrm{MgO}-\mathrm{MgSO}_{4}-\mathrm{H}_{2} \mathrm{O}$ system at different temperatures from 30 to $120{ }^{\circ} \mathrm{C}$. These phases are $5 \mathrm{Mg}(\mathrm{OH})_{2} \cdot \mathrm{MgSO}_{4} \cdot 3 \mathrm{H}_{2} \mathrm{O}$ (or $2 \mathrm{H}_{2} \mathrm{O}$ ) (the 513 phase), $3 \mathrm{Mg}(\mathrm{OH})_{2} \cdot \mathrm{MgSO}_{4} \cdot 8 \mathrm{H}_{2} \mathrm{O}$ (the 318 phase), $\mathrm{Mg}(\mathrm{OH})_{2} \cdot \mathrm{MgSO}_{4} \cdot 5 \mathrm{H}_{2} \mathrm{O}$ (the 115 phase), and $\mathrm{Mg}(\mathrm{OH})_{2} \cdot 2 \mathrm{MgSO}_{4} \cdot 3 \mathrm{H}_{2} \mathrm{O}$ (the 123 phase). The generation of the different phases is dependent on the different temperatures, stability, and strengths. Urwong and Sorrel [11] investigated the phase relationship in MOS cement and identified many stable phases at $23^{\circ} \mathrm{C}$, namely $3 \mathrm{Mg}(\mathrm{OH})_{2} \cdot \mathrm{MgSO}_{4} \cdot 8 \mathrm{H}_{2} \mathrm{O}$ (the 318 phase), the metastable $\mathrm{Mg}(\mathrm{OH})_{2} \cdot \mathrm{MgSO}_{4} \cdot 5 \mathrm{H}_{2} \mathrm{O}$ (the 115 phase), $\mathrm{Mg}(\mathrm{OH})_{2}$ and $\mathrm{MgO}$, plus $\mathrm{MgSO}_{4} \cdot \mathrm{nH}_{2} \mathrm{O}(\mathrm{n}=1,6$ and 7). Kahle [12] determined that the stable 318 phases and the 513 phases existed in hardened thiomagnesium cementitious materials when the mixing ratio of $\mathrm{MgO}$ and magnesium sulfate was 5:1, under saturated steam pressure curing conditions. Vincenzo [13] found that at low temperatures, the phase produced by oxysulfate 
cement was the 318 phase; the mechanical properties of the thiomagnesium cementitious material after hardening were poor, but the water resistance was very good.

Previous studies have shown that an adjustment of the crystal phase composition and a reduction in the formation of unwanted phases may be an effective method to improve the mechanical strength of MOS cement. Yu [14] investigated changes in the hydration process and the composition of $\mathrm{MgO}$. The addition of phosphoric acid and phosphate increases the compressive strength and the water resistance of MOS cement, forming $\mathrm{MgSO}_{4} \cdot 7 \mathrm{H}_{2} \mathrm{O}$ (the 517 phase); this phase is needle-like and insoluble in water. In addition, Yu also determined that the curing conditions had a large impact on the deformation of MOC cement; the results indicated that the expansion value of the cement for moisture curing was 10 times that of natural curing and the expansion value for natural curing was 10 times that of dry curing. Previous research on MOC cement [15-17] has shown that the chemical reactions, reaction products, and mechanical strength depend on the maintenance methods, raw materials, etc.

It is known that the behaviour of cement-based materials is affected by the curing methods [18-19]. However, few reports have been published on how to achieve the best performance for MOS cement. Therefore, in this study, we have investigated the effects of different curing temperatures and curing methods on the performance of the reaction products and mechanical strength of the cement.

We conducted an in-depth study of MOS cement and investigated the effect of different curing temperatures and curing methods on the compressive strength of glass fibre reinforced basic magnesium sulfate cement (GRBMS). The strength development, phase composition, and microstructure of the MOS cement are investigated in detail to determine the hardening mechanism and the optimal curing methods. Glass fibres are added to the basic magnesium sulfate cement (BMSC) to improve its durability. Yu [20] used the stand-in cement (SIC) test method to compare a highperformance GRMC and a conventional GRMC, which was not modified, using an accelerated aging test with $80{ }^{\circ} \mathrm{C}$ water, compared to the double-blended composite water-resistant additive and slag. The bending strength retention and the service life were low. Liu Qianqian [21] studied the degradation of the mechanical properties of GRMC using accelerated aging with $50{ }^{\circ} \mathrm{C}$ and $80{ }^{\circ} \mathrm{C}$ water and determined the durability of a glass fibrereinforced MOC. The results indicated that the glass fibre provided excellent anti-aging properties for the BMSC.

The results of the above-mentioned studies show that the mechanical properties of the sulfoxy magnesium cementitious materials and the phase composition of the hydration products are closely related to the temperature conditions of the environment. Therefore, the temperature stability of the sulfoxy magnesium cementitious materials has been investigated to determine the mechanical properties and the crystal phases. The stability is of great significance. Two curing temperatures and two curing methods were tested to ascertain the changes in the mechanical properties and phase composition of the GRBMS and X-ray diffraction (XRD) phase analysis was performed. Scanning electron microscopy (SEM) was used to analyse the phase characteristics and morphology of the hydration products and determine the effects of the curing conditions on the performance of the GRBMS and the underlying mechanism.

\section{EXPERIMENTAL}

\section{Materials}

The magnesia used for the production of calcined magnesite at $750{ }^{\circ} \mathrm{C} \quad\left(1382{ }^{\circ} \mathrm{F}\right)$ was light-burned magnesia (LBM) obtained from Dashiqiao Liaoning Province, China. The content of high-activity $\mathrm{MgO}$ (a-MgO) was determined using the standardised hydration method of Dong Jinmei [22]; the content was only $58.92 \%$. The a-MgO hydrates and is converted to magnesium subsulfate in a magnesium sulfate solution during the setting of the MOS cement [23-24]. The chemical composition is shown in Table 1. The mineral components are $\mathrm{MgO}$, quartz $\left(\mathrm{SiO}_{2}\right)$, as well as a small amount of magnesium carbonate $\left(\mathrm{MgCO}_{3}\right)$, calcium carbonate $\left(\mathrm{CaCO}_{3}\right)$, and hydrated magnesium silicate $\left(\mathrm{Mg}_{3} \mathrm{Si}_{4} \mathrm{O}_{10}(\mathrm{OH})_{2}\right)$. The chemical composition of the analytically pure magnesium sulfate $\left(\mathrm{MgSO}_{4} \cdot 7 \mathrm{H}_{2} \mathrm{O}\right)$ is shown in Table 2. Sodium citrate $\left(\mathrm{C}_{6} \mathrm{H}_{8} \mathrm{Na}_{3} \mathrm{O}_{7} \cdot 2 \mathrm{H}_{2} \mathrm{O}\right)$ was purchased from Tianjin Chemio Chemical Co., Ltd. As shown in Equations 1 and 2, at an equimolar ratio, the active magnesium oxide in the LBM reacts with the magnesium sulfate to form a stable strength of the 517 phase (or the 513 phase) and a 517 intensity phase, during dehydration at high temperature, the 513 phase is formed, as shown in Equation 3.

$$
\begin{gathered}
5 \mathrm{MgO}+\mathrm{MgSO}_{4}+12 \mathrm{H}_{2} \mathrm{O} \rightarrow \\
\rightarrow 5 \mathrm{Mg}(\mathrm{OH})_{2} \cdot \mathrm{MgSO}_{4} \cdot 7 \mathrm{H}_{2} \mathrm{O} \\
5 \mathrm{MgO}+\mathrm{MgSO}_{4}+7 \mathrm{H}_{2} \mathrm{O} \rightarrow \\
\rightarrow 5 \mathrm{Mg}(\mathrm{OH})_{2} \cdot \mathrm{MgSO}_{4} \cdot 3 \mathrm{H}_{2} \mathrm{O} \\
\\
5 \mathrm{Mg}(\mathrm{OH})_{2} \cdot \mathrm{MgSO} \mathrm{Mg}_{4} \cdot 7 \mathrm{H}_{2} \mathrm{O}-4 \mathrm{H}_{2} \mathrm{O} \rightarrow \\
\rightarrow 5 \mathrm{Mg}(\mathrm{OH})_{2} \cdot \mathrm{MgSO}_{4} \cdot 3 \mathrm{H}_{2} \mathrm{O}
\end{gathered}
$$

The wood chips used in this study were passed through a 20-mesh sieve. In addition, a mid-alkali glass mesh fabric (Xinhui Chemical Company, Xining City) with an average monofilament diameter of $13 \mu \mathrm{m}$ and a mesh size of $8 \mathrm{~mm} \times 4 \mathrm{~mm}$ was used to improve the flexural strength and overall toughness of the GRBMS. The chemical composition of the fabric is shown in Table 3 . 
Table 1. The chemical composition of the light burned magnesium (LBM).

$\begin{array}{lllllll}\text { Chem. composition } & \mathrm{MgO} & \mathrm{CaO} & \mathrm{SiO}_{2} & \mathrm{Fe}_{2} \mathrm{O}_{3} & \mathrm{Al}_{2} \mathrm{O}_{3} & \text { IL }\end{array}$

\begin{tabular}{lllllll} 
Mass fraction (\%) & 80.20 & 1.30 & 6.07 & 0.41 & 0.15 & 11.87 \\
\hline
\end{tabular}

Table 2. The chemical composition of $\mathrm{MgSO}_{4} \cdot 7 \mathrm{H}_{2} \mathrm{O}$.

Chem. composition $\mathrm{MgSO}_{4} \quad \mathrm{MgCl}_{2} \mathrm{NaCl} \quad \mathrm{Na}_{2} \mathrm{SO}_{4} \mathrm{H}_{2} \mathrm{O}$ Other

\begin{tabular}{lllllll}
\hline Weight (\%) & 47.85 & 0.5 & 0.5 & 0.5 & 50.24 & 0.41
\end{tabular}

Table 3. The chemical composition of the mid-alkali glass mesh fabric.

Chem. composition $\quad \mathrm{SiO}_{2} \quad \mathrm{CaO} \quad \mathrm{Al}_{2} \mathrm{O}_{3} \quad \mathrm{MgO} \quad \mathrm{Fe}_{2} \mathrm{O}_{3} \quad \mathrm{Na}_{2} \mathrm{O}$

\begin{tabular}{lllllll}
\hline Mass fraction (\%) & 67.30 & 9.50 & 6.07 & 4.20 & 0.93 & 12.00
\end{tabular}

\section{Preparation of GRBMS}

The GRBMS has an a-MgO/MgSO 4 molar ratio $\mathrm{M}$ of 6 , a is the light burned magnesium oxide activity. The wood chips comprise $20 \%$ of the cement and the watercement ratio is 0.35 . The composition of the GRBMS specimens is shown in Table 4 according to the above calculation of the amount of each admixture. $\mathrm{MgSO}_{4} \cdot 7 \mathrm{H}_{2} \mathrm{O}$ was dissolved in water to form a 25.00 mass. $\% \mathrm{MgSO}_{4}$ solution. The prepared magnesium sulfate solution was mixed with water and then the magnesia, sodium citrate, and the wood chips were added and stirred for $90 \mathrm{~s}$ (slow for $60 \mathrm{~s}$ and fast for $30 \mathrm{~s}$ ) and then added into 24 steel moulds with dimensions of $40 \mathrm{~mm} \times 40 \mathrm{~mm} \times 160 \mathrm{~mm}$ by the following procedure. First, $50 \mathrm{~g}$ of the mixed slurry with a protective layer was poured into the moulds. Next, adding three layers of grid cloth and then the remaining slurry was poured into steel moulds, which were vibrated twice to level the mixture. After the samples were moulded, six steel moulds were placed in a vacuum curing box at a temperature of $50{ }^{\circ} \mathrm{C}$ for $7 \mathrm{~d}$, after which they were demoulded and continued to cure naturally $(20 \pm 2){ }^{\circ} \mathrm{C}$ for $28 \mathrm{~d}$. An additional six steel moulds were cured at $20{ }^{\circ} \mathrm{C}$ for $24 \mathrm{~h}$, were demoulded and cured at $50{ }^{\circ} \mathrm{C}$ for $7 \mathrm{~d}$, followed by natural curing for $28 \mathrm{~d}$. The remaining 12 steel moulds were maintained at $80^{\circ} \mathrm{C}$ and the curing conditions were the same as for the samples cured at $50{ }^{\circ} \mathrm{C}$.

Symbol Description: $\mathrm{T}$ represents the curing temperature, $\mathrm{P}$ represents the samples that are cured directly after demoulding, $\mathrm{N}$ are the samples with the mould maintenance. For example: T5OP represents the samples after $24 \mathrm{hr}$ of natural curing, followed by mould removal, placing in a vacuum curing box at $50{ }^{\circ} \mathrm{C}$ for $7 \mathrm{~d}$, and natural curing for $28 \mathrm{~d}$; T50N represents the samples kept in the mould at a temperature of $50{ }^{\circ} \mathrm{C}$, placed in the vacuum curing box for curing for $7 \mathrm{~d}$, followed by demoulding and natural curing for $28 \mathrm{~d}$.

\section{Specimen analysis}

The compressive strengths of the GRBMS samples cured for different periods $(12 \mathrm{~h}, 1 \mathrm{~d}, 3 \mathrm{~d}, 7 \mathrm{~d}, 28 \mathrm{~d})$ were tested on a testing machine using a maximum force of $100 \mathrm{kN}$ at a loading rate of $10 \mathrm{~mm} \cdot \mathrm{min}^{-1}$. The flexural strengths of the GRBMS samples were tested with a TYE-10C compressive and flexural tester. Three samples were tested for each curing age and composition. The specimens that underwent various curing conditi-ons were sampled at $12 \mathrm{~h}, 1 \mathrm{~d}, 3 \mathrm{~d}, 7 \mathrm{~d}$, and $28 \mathrm{~d}$ and they were left in small pieces. After soaking in ethanol for $48 \mathrm{hr}$, the samples were removed and ground in a grinding dish. The powder was sampled and sieved in a $0.08 \mathrm{~mm}$ sieve. The crushed cement was reduced to a power (D90/5 lm) for the crystal phase composition analysis performed with an X' Pert PRO (PANalytical) diffractometer with $\mathrm{CuK} \alpha$ radiation $(\lambda=0.15419 \mathrm{~nm})$ over a $2 \theta$ range from 50 to 700 . The microstructure of the GRBMS samples cured at $50{ }^{\circ} \mathrm{C}$ and $80{ }^{\circ} \mathrm{C}$ for $1 \mathrm{~d}$ and cured naturally for $28 \mathrm{~d}$ was characterised by SEM (JSM-5610LV); the fractured surfaces of the samples were coated with gold. The porosity and pore distribution of the GRBMS cement cured in air for $28 \mathrm{~d}$ were determined using the mercury intrusion porosimetry (MIP) method using an automatic mercury porosimeter (Auto Pore IV 9500). In addition, the sample cured for $28 \mathrm{~d}$ was immersed in water and its water resistance was determined after 1 month. The water resistance coefficient (Rw) was used as a quantitative measure of the water resistance performance of the GRBMS-based composites. It was calculated using the following equation:

$$
\mathrm{RW}=\mathrm{F}_{\mathrm{cs}} / \mathrm{F}_{28}
$$

where $\mathrm{F}_{28}$ is the average 28-day compressive strength of the specimen under each specified curing regime, (MPa); $\mathrm{F}_{\mathrm{cs}}$ is the average compressive strength of the specimen after completing the prolonged water immersion, (MPa).

Table 4. The ratio of the GRBMS specimens.

\begin{tabular}{lccccccr}
\hline $\begin{array}{l}\text { Sample } \\
\text { ratio }\end{array}$ & $\mathrm{MgO} / \mathrm{MgSO}_{4}$ & $a-\mathrm{MgO}$ & $\begin{array}{c}\text { with } \\
\mathrm{MgO} \\
(\mathrm{g})\end{array}$ & $\begin{array}{c}\text { with } \\
\mathrm{MgSO}_{4} \cdot 7 \mathrm{H}_{2} \\
(\mathrm{~g})\end{array}$ & $\begin{array}{c}\text { with } \\
\mathrm{C}_{6} \mathrm{H}_{8} \mathrm{Na}_{3} \mathrm{O}_{7} \cdot 2 \mathrm{H}_{2} \mathrm{O} \\
(\mathrm{g})\end{array}$ & $\begin{array}{c}\text { with } \\
\text { wood chips } \\
(\mathrm{g})\end{array}$ & $\begin{array}{c}\text { with } \\
\mathrm{H}_{2} \mathrm{O} \\
(\mathrm{g})\end{array}$ \\
\hline GRBMS & 6 & $58.92 \%$ & 497.14 & 300.24 & 2.63 & 160 & 50.41 \\
\hline
\end{tabular}




\section{RESULTS AND DISCUSSION}

Mechanical strength

The flexural strength of the GRBMS specimens for different curing methods and temperatures is shown in Figure 1a. It can be seen that an increase in the curing temperature significantly improves the early strength. For instance, after curing for $1 \mathrm{~d}$, the flexural strength of T50P and T80P was $8.721 \mathrm{MPa}$ and $8.149 \mathrm{MPa}$, respectively, which was $180 \%$ and $162 \%$ higher than the flexural strength of $3.120 \mathrm{MPa}$ at $20^{\circ} \mathrm{C}$ for the same curing age, respectively. In contrast, the flexural strength of $\mathrm{T} 50 \mathrm{~N}$ and $\mathrm{T} 80 \mathrm{~N}$ was $7.248 \mathrm{MPa}$ and $7.801 \mathrm{MPa}$ representing an increase in the flexural strength by $132 \%$ and $150 \%$ compared to T20, respectively. After $7 \mathrm{~d}$ of curing at $50{ }^{\circ} \mathrm{C}$ in the early stage and after curing at $20{ }^{\circ} \mathrm{C}$ for $28 \mathrm{~d}$, the flexural strength of T50P and T50N increased by $17.7 \%$ and $0.37 \%$, whereas for the early curing temperature of $80{ }^{\circ} \mathrm{C}$, the flexural strength increased by $40.9 \%$ and $12.9 \%$, respectively. According

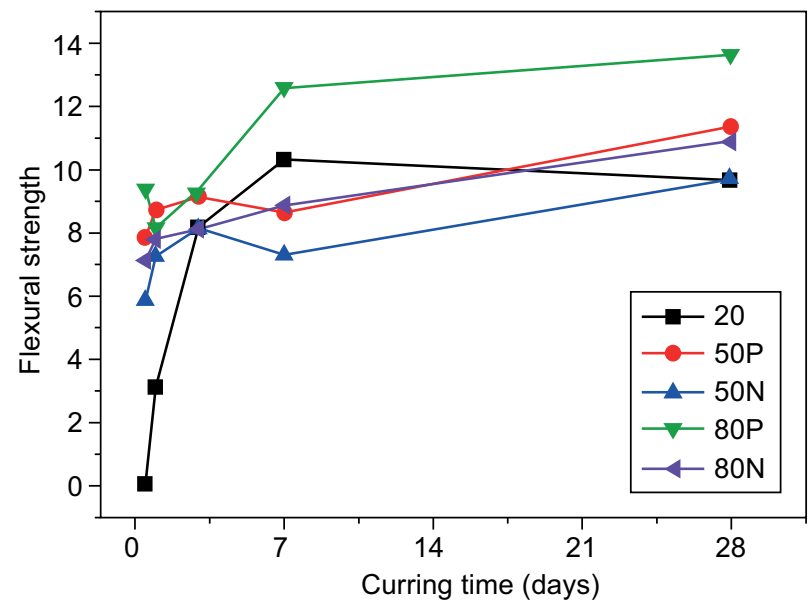

a) the flexural strength

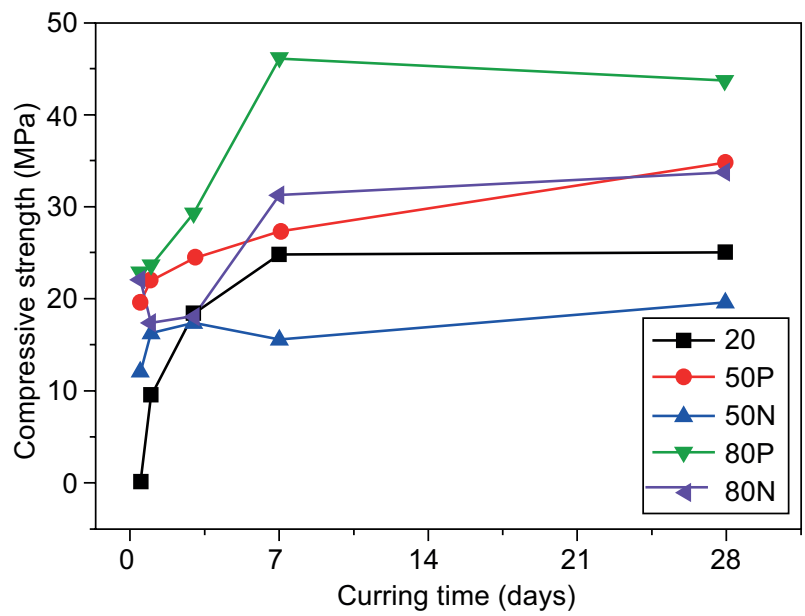

b) the compressive strength

Figure 1. The flexural (a) and compressive (b) strengths of the GRBMS at different temperatures for the strip $(\mathrm{N})$ and direct (P) curing methods. to the results reported by Wen [25], an increase in the flexural strength is the result of the formation of new phases in the cementitious system. However, the glass fibres were added to the bottom of the test piece. Because the fibres possess toughness and strong tensile properties, they improve the tensile strength. As shown in Figure 2, although the glass fibre had some cement residue adhere to it during the hydration process, the fibre is smooth and has no obvious chemical corrosion defect. The mutual bonding force between the glass fibre and the cement base is similar to that between steel and concrete. As the hydration reaction proceeds, no chemical reaction takes place between the glass fibres and the cement. The results indicate that the pre-curing strength was slightly lower at the curing temperature of $80{ }^{\circ} \mathrm{C}$ than at $50{ }^{\circ} \mathrm{C}$ when cured at high temperatures for $1 \mathrm{~d}$, whereas the strength was slightly higher for the direct high-temperature curing. The reason is that prior to the high-temperature curing, the specimen was first cured at $20^{\circ} \mathrm{C}$ for $1 \mathrm{~d}$ and was then cured at $80{ }^{\circ} \mathrm{C}$. The hydration reaction is sufficiently fast so that the hydration product forms later and the dispersion type of the flexural strength is relatively large. When the specimens remain in the mould, the temperature does not change much; therefore, the hydration rate is not very high. The late strength was slightly higher at $80{ }^{\circ} \mathrm{C}$ than at $50{ }^{\circ} \mathrm{C}$ and this was most evident for T80P.

Figure $1 \mathrm{~b}$ shows the compressive strength of the GRBMS specimens for the different curing methods and
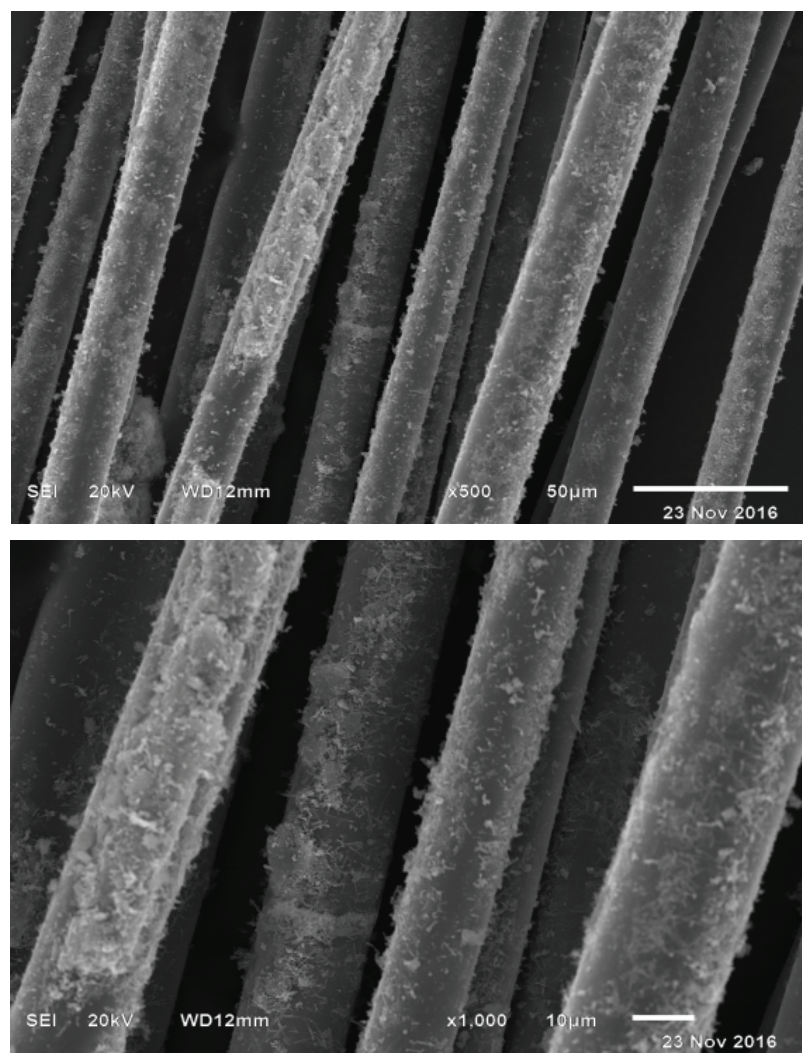

Figure 2. A cross-section of the glass fibre and cement slurry 
temperatures. The results are similar to those shown in Figure 1a. The difference is that the compressive strength is higher for $\mathrm{T}(\mathrm{n}) \mathrm{P}$ than for $\mathrm{T}(\mathrm{n}) \mathrm{N}$ in the early or late stage of high-temperature curing. For example, after $12 \mathrm{~h}$ of curing, the compressive strength of T50P and T50N was 19.675 MPa and $12 \mathrm{MPa}$, and the compressive strength was $34.8 \mathrm{MPa}$ and $19.6 \mathrm{MPa}$, respectively, when the specimens were cured for $28 \mathrm{~d}$. The early compressive strength of T80P was $3.4 \%$ higher than that of T $80 \mathrm{~N}$ and $29.5 \%$ after $28 \mathrm{~d}$. Therefore, at a suitable temperature, the higher the temperature, the higher the late compressive strength is for direct curing; this curing method improves the durability of the cement. [26]

\section{Porosity}

The mechanical strength of the GRBMS cement is closely related to the type and content of the hydration products and the porosity and pore distribution. It is observed in Figure 3 that the cumulative porosity (from $333 \mathrm{~lm}$ to $6.0 \mathrm{~nm}$ ) of the T80P specimen is $32.02 \%$ lower than that of T80N (from $334 \mathrm{~lm}$ to $6.0 \mathrm{~nm}$ ). The difference between T50P and T80P is relatively small. Table 5 shows that there are significant differences in the porosity and pore size distribution of the specimens. The porosity of T50P is significantly lower than that of T80P, which is attributed to the difference in the hydration products at the different temperatures. The pore size of the T80N specimen is $3027 \mathrm{~nm}$, which is nearly three times that of T80P. The reason may be due to the differences in the morphology of the hydration products produced by the two curing modes at the same temperature. In addition, the wood chips in the GRBMS cement also increase the pore size. In the GRBMS cement, the most common types of pores are small pores $(10 \mathrm{~nm} \sim 100 \mathrm{~nm})$ and macropores $(D>100 \mathrm{~nm})$, whereas gel pores $(D<10 \mathrm{~nm})$ are the results of poorly crystallised hydration products.

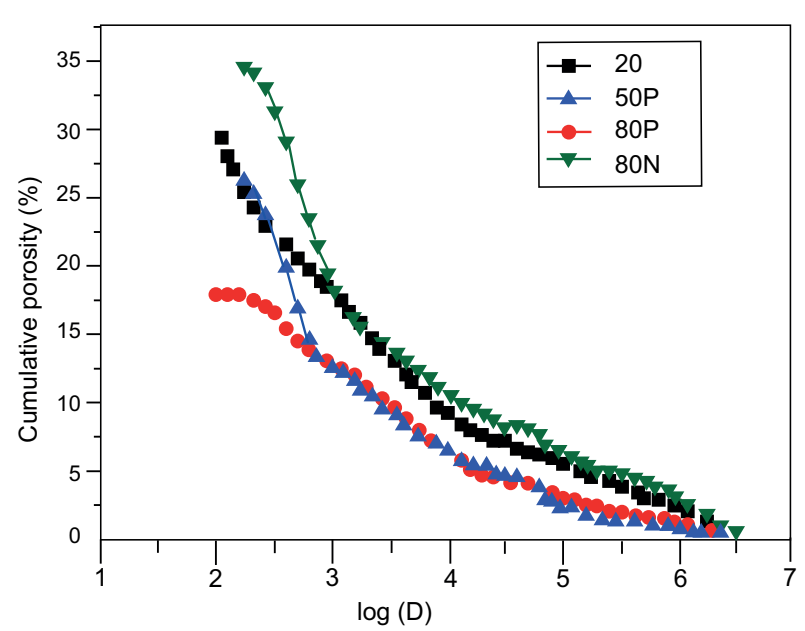

Figure 3. The cumulative porosity of the GRBMS cement for the different curing conditions [D is the pore diameter $(\mathrm{nm})]$.

Table 5. The pore size distribution for the different types of GRBMS cement.

\begin{tabular}{lccccc}
\hline \multicolumn{3}{c}{ Average Pore } & & & \\
Sample & Diameter & Porosity & $<10 \mathrm{~nm}$ & $10-100 \mathrm{~nm}$ & $>100 \mathrm{~nm}$ \\
& $(\mathrm{~nm})$ & $(\%)$ & $(\%)$ & $(\%)$ & $(\%)$ \\
\hline 20 & 261 & 24.29 & 25.65 & 40.88 & 33.47 \\
$50-\mathrm{P}$ & 941 & 13.14 & 6.09 & 50.53 & 43.38 \\
$80-\mathrm{P}$ & 982 & 22.42 & 0 & 63.34 & 36.66 \\
$80-\mathrm{N}$ & 3027 & 32.96 & 0 & 45.93 & 54.07 \\
\hline
\end{tabular}

The small pores (10 $\mathrm{nm}$ to $100 \mathrm{~nm}$ ) are crystalline pores, and the larger the number, the better the crystallinity of the hydrated product and the higher the strength is.

Phase transformation

The XRD patterns of the GRBMS-based composites cured using the five curing methods are shown in Figure 4. It is observed that at a curing temperature of $50{ }^{\circ} \mathrm{C}$, the

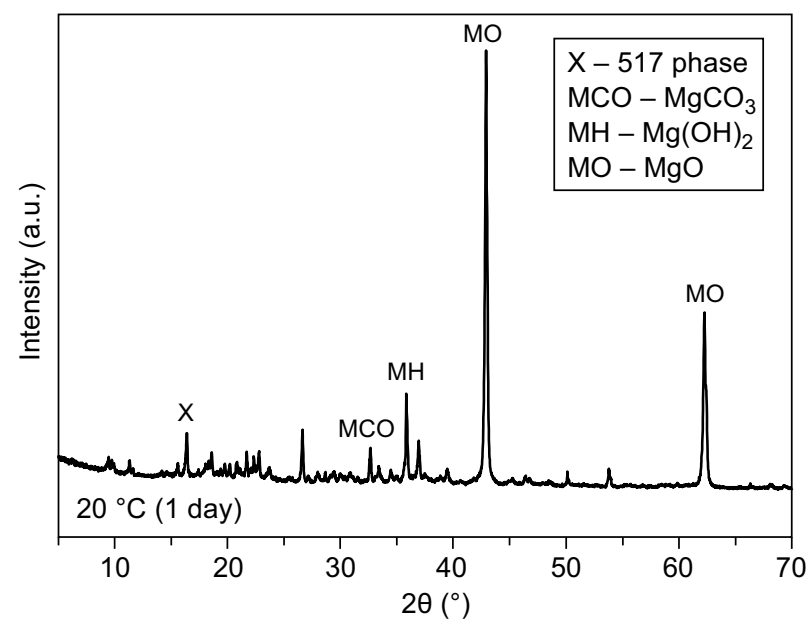

a) XRD patterns of $T 20$ at $1 \mathrm{~d}$

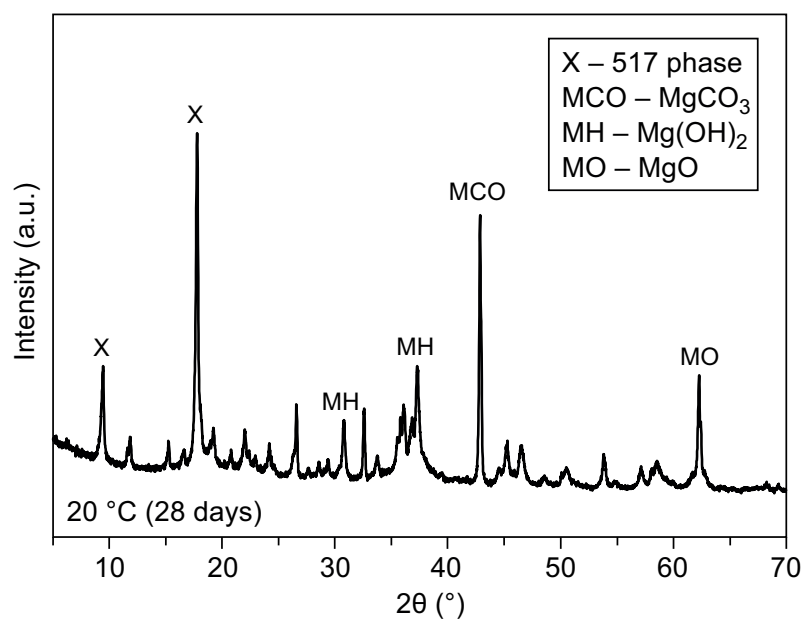

b) XRD patterns of T20 at $28 \mathrm{~d}$

Figure 4. The XRD patterns of the GRBMS cement-based composites using five curing regimes. (Continue on next page) 


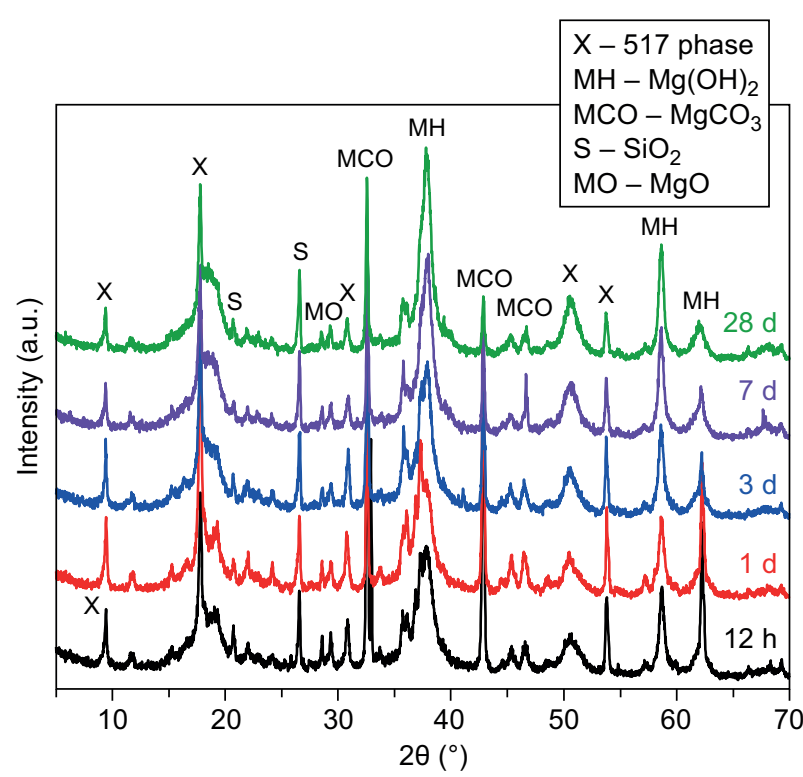

c) XRD patterns of T50P

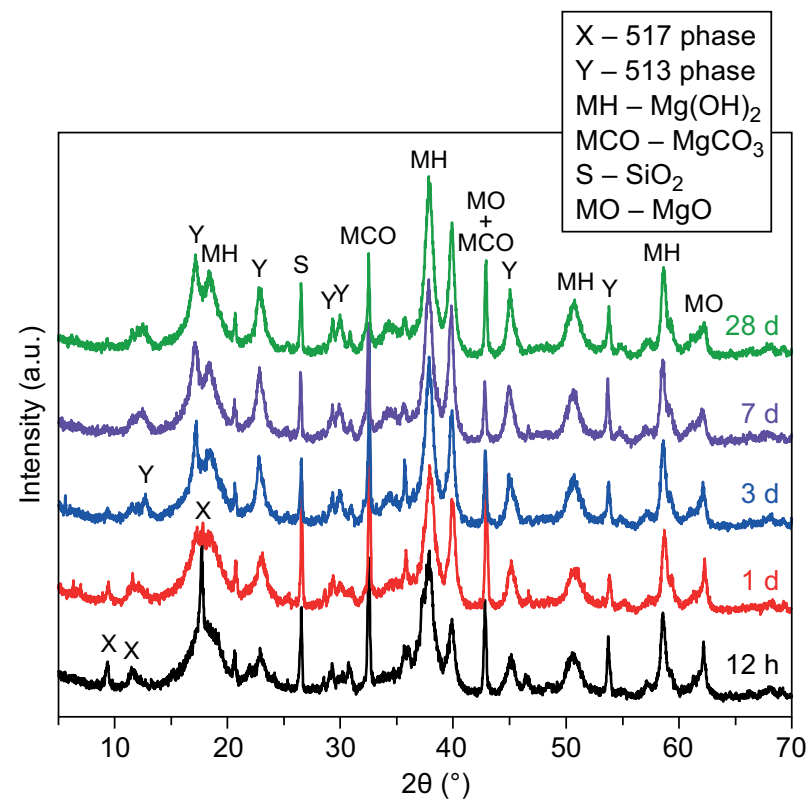

e) XRD patterns of T80P

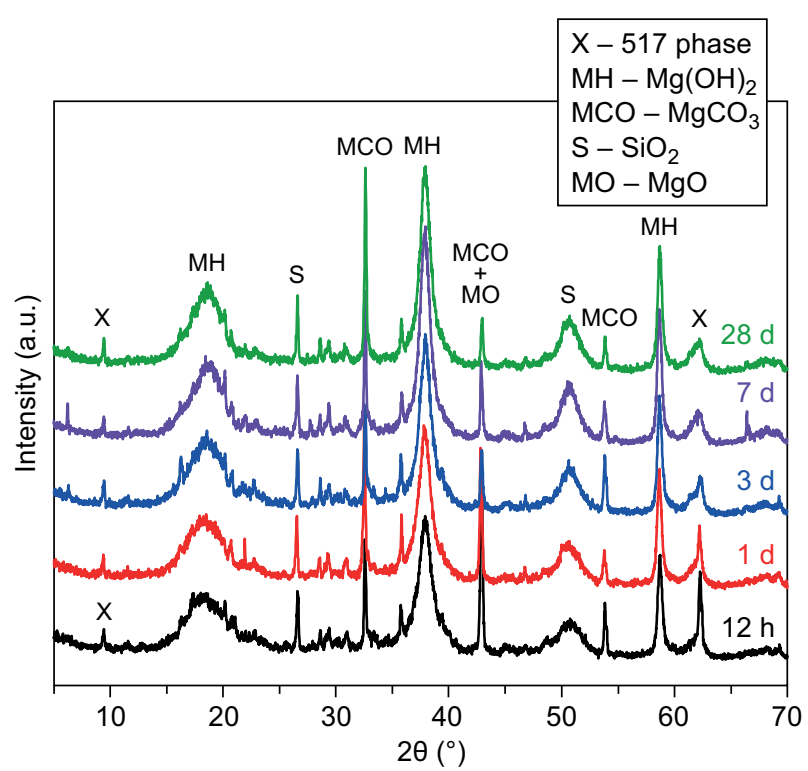

d) XRD patterns of $T 50 \mathrm{~N}$

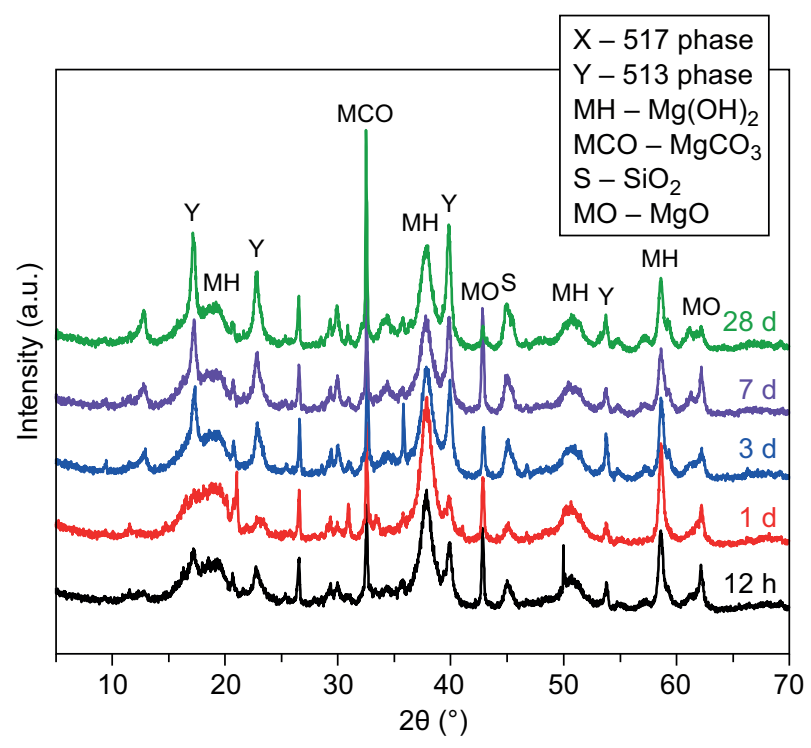

f) XRD patterns of $\mathrm{T} 80 \mathrm{~N}$

Figure 4. The XRD patterns of the GRBMS cement-based composites using five curing regimes.

main strength phase was the 517 phase. The formation of the 517 phase is described by Equation 5 and Equation 6 [27]. Compared with the results of curing at $20{ }^{\circ} \mathrm{C}$, the intensity of the diffraction peak of $\mathrm{MgO}$ decreased significantly after $28 \mathrm{~d}$, indicating that high temperature curing has a higher degree of hydration, which is the main reason why the compressive strength is slightly higher than at $20^{\circ} \mathrm{C}$. When the specimen was directly cured at $80^{\circ} \mathrm{C}$, the hydration strength phase changed significantly. For a hydration period of $3 \mathrm{~d}$, the strength phase changed from the 517 phase to the 513 phase, which was the main reason for the decrease in the 3-d flexural strength at $12 \mathrm{~h}$ when the specimen was cured at $80^{\circ} \mathrm{C}$. The XRD patterns of the specimens cured at a temperature of $50{ }^{\circ} \mathrm{C}$ (Figure
$4 c, d)$ indicate that the diffraction peak of the 517 phase in Figure $4 \mathrm{a}$ is obviously stronger than that shown in Figure $4 \mathrm{~b}$, and there is a shift of 17 degrees in the diffraction peak of $\mathrm{Mg}(\mathrm{OH})_{2}$ because pre-foster curing is beneficial to the hydration reaction and promotes the formation of the 517 intensity phase.

$$
\begin{gathered}
\mathrm{MgO}+(\mathrm{x}+1) \mathrm{H}_{2} \mathrm{O} \rightarrow\left[\mathrm{Mg}(\mathrm{OH})\left(\mathrm{H}_{2} \mathrm{O}\right)_{\mathrm{X}}\right]^{+}+\mathrm{OH}^{-} \\
2\left[\mathrm{Mg}(\mathrm{OH})\left(\mathrm{H}_{2} \mathrm{O}\right)_{\mathrm{X}}\right]^{+}+\mathrm{SO}_{4}{ }^{2-}+4 \mathrm{Mg}^{2+}+8 \mathrm{OH}^{-} \rightarrow \\
\rightarrow 5 \mathrm{Mg}(\mathrm{OH})_{2}-\mathrm{MgSO}_{4}-7 \mathrm{H}_{2} \mathrm{O}+(2 \mathrm{x}-7) \mathrm{H}_{2} \mathrm{O}
\end{gathered}
$$

Compared with the results for the curing at $50^{\circ} \mathrm{C}$, significant changes are observed for curing at $80^{\circ} \mathrm{C}$. It can be seen from the XRD patterns in Figure 4e that some of the 517 phase is produced in the early stage of pre-curing 
at $80{ }^{\circ} \mathrm{C}$. After curing for $3 \mathrm{~d}$ at high temperature, the 517 phase in the hydrated product is converted to the 513 phase because the GRBMS cement was hydrated at $20{ }^{\circ} \mathrm{C}$ for $1 \mathrm{~d}$ prior to high-temperature curing. The main hydration products of the GRBMS at room temperature were the 517 phase, $\mathrm{Mg}(\mathrm{OH})_{2}$, and $\mathrm{MgCO}_{3}$; when the specimens were cured at $80^{\circ} \mathrm{C}$, the 517 phase dehydrated to the 513 phase, increasing the intensity.

With the increase in the curing time, magnesium oxide continues to hydrate and the intensity of the 513 phase increases, which increases the strength in the later stage. Figure $4 \mathrm{f}$ shows the XRD patterns of the specimen cured at $80{ }^{\circ} \mathrm{C}$. This curing method does not result in the formation of the 517 phase, but directly produces the 513 phase, which is the main reason for the lower strength compared to T80P. In addition, the diffraction peak intensity of $\mathrm{MgCO}_{3}$ is significantly higher and the diffraction peak of $\mathrm{Mg}(\mathrm{OH})_{2}$ is slightly lower, which is one of the reasons for the low strength. Considering the difference in the flexural strength and compressive strength, it can be concluded that the order of strength of the hydrated phase is $517>513>\mathrm{Mg}(\mathrm{OH})_{2}$ for the flexural strength and $517 \approx 513 \gg \mathrm{Mg}(\mathrm{OH})_{2}$ for the compressive strength.

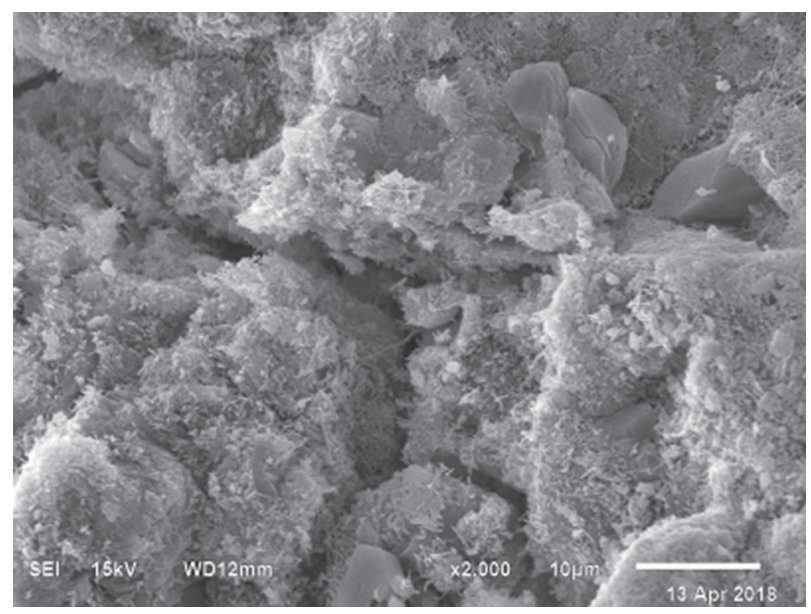

a) 1 day

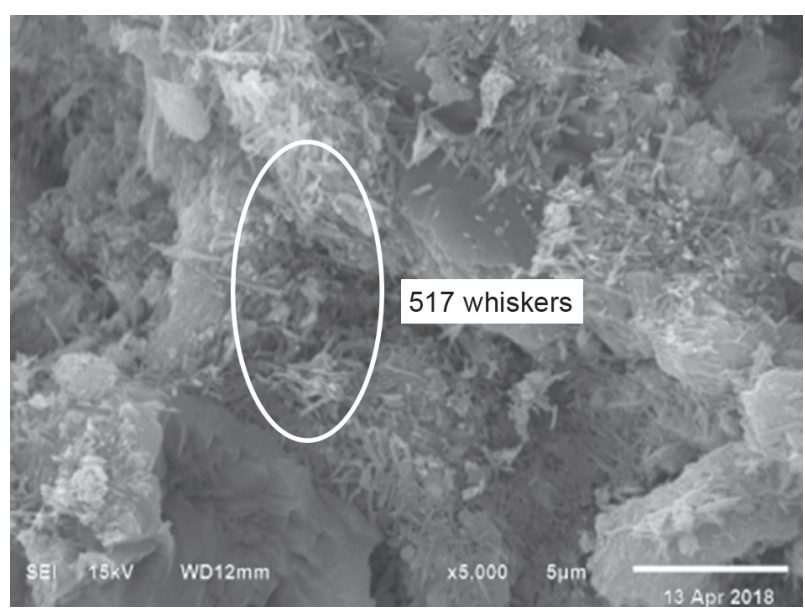

b) 1 day

\section{SEM}

The microstructure of the composite materials is another important factor affecting the mechanical strength. Figure 5 shows the SEM images of the GRBMS matrix cured for $1 \mathrm{~d}$ and $28 \mathrm{~d}$ at $20^{\circ} \mathrm{C}$. Figure 5a shows many white gel-like substances that are hydrated when cured under natural conditions for $1 \mathrm{~d}$. The $5000 \times$ magnification of the SEM image clearly shows that the short and thick fibrous whiskers are not only the 517 phases, indicating that there are a large number of intensity phases that were generated during curing at $20{ }^{\circ} \mathrm{C}$ for $1 \mathrm{~d}$; this morphology explains the high early strength of the T(n)P.

The morphology of the matrix of the composite cured for $28 \mathrm{~d}$ at a temperature of $20{ }^{\circ} \mathrm{C}$ is shown in Figure $5 \mathrm{c}$. It is apparent that a large number of needle crystals occurs in the voids and the needle crystals are the 517 phases. Compared with Figure 5b, the microstructure exhibits more detail and the morphology of the 517 phase is more apparent, which is mainly due to the incomplete hydration of $\mathrm{MgO}$ in the early stage. Therefore, the matrix contains a large amount of $\mathrm{MgO}$ and $\mathrm{Mg}(\mathrm{OH})_{2}$. In the later stage, with the prolongation of the curing time, the magnesium oxide continues to hydrate, the content of the strength of the 517 phase increases, and the morphology gradually changes into a needle-like structure, which explains the higher compressive strength in the later stage.

Figure 6 shows the SEM images of the matrix of the composite cured at $50{ }^{\circ} \mathrm{C}$ and $80{ }^{\circ} \mathrm{C}$ for $1 \mathrm{~d}$ and 28 $\mathrm{d}$. Figure $6 \mathrm{a}$ and $\mathrm{b}$ show the morphology of the specimen cured at $50{ }^{\circ} \mathrm{C}$. It is evident that the morphology differs for the specimens cured under the different conditions. Careful observation of the pore areas of 50-P and 50-N indicates that the morphology of the 517 phase crystals is slightly different. For example, the crystals in 50-P are significantly longer and sharper than the 517 phase crystals in $50-\mathrm{N}$ and the needles are more pronounced. However, these are much smaller in size in 50-N and are

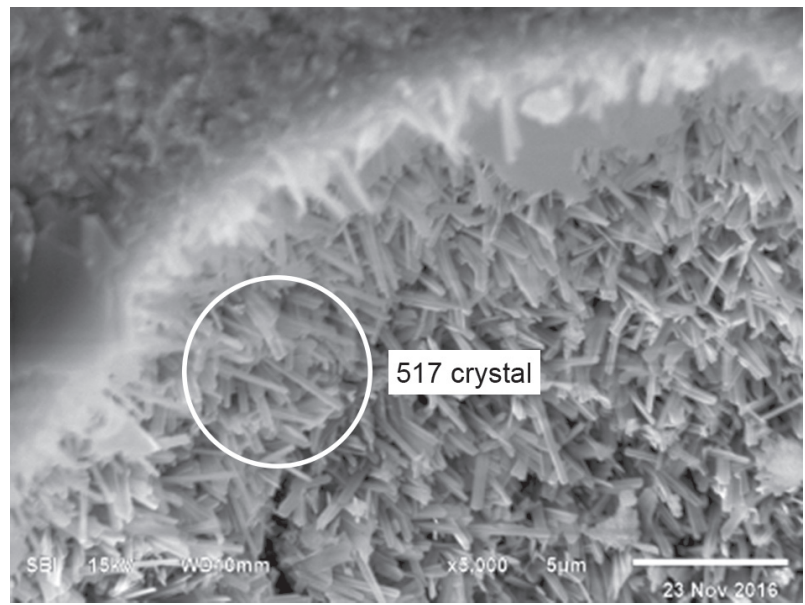

c) 28 days

Figure 5. SEM image of the GRBMS specimens curing for $1 \mathrm{~d}$ and $28 \mathrm{~d}$ at $20^{\circ} \mathrm{C}$. 
densely meshed. The observed morphological changes in the 517 phase crystals may be caused by the different curing modes.

The SEM images of the GRBMS specimen cured at $80^{\circ} \mathrm{C}$ are shown in Figures $6 \mathrm{a}$ and $\mathrm{b}$. Figure $6 \mathrm{c}$ shows the SEM image of the GRBMS sample cured directly and at an elevated temperature. The pore morphology was observed after curing at a high temperature for $1 \mathrm{~d}$; a small

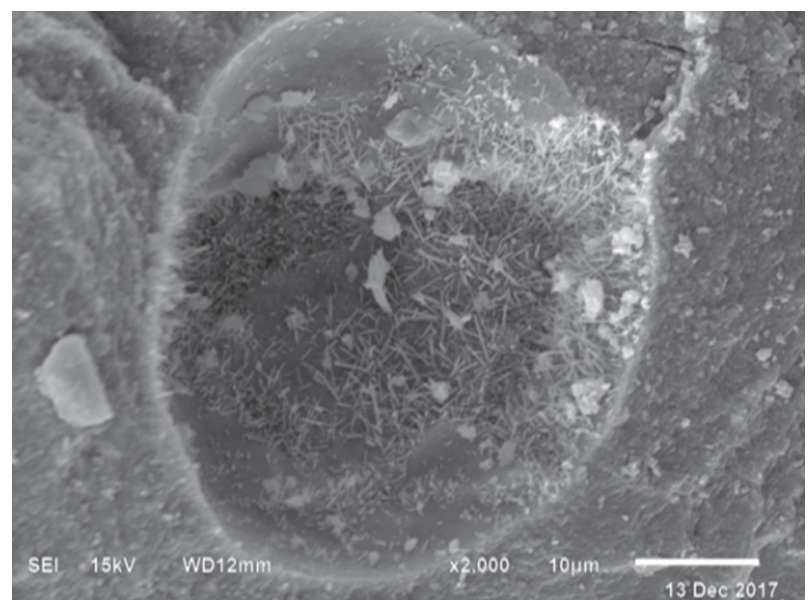

number of white crystals occurs in the pores and adheres to the upper edge of the pores; these are unformed 517 whiskers. After curing at high temperature for $7 \mathrm{~d}$, the specimen was cured at $20^{\circ} \mathrm{C}$ for $28 \mathrm{~d}$; a large number of needle-like 517 phases in the hole are converted into a sheet of the 513 phase, in which the whiskers are mixed with the short fibres.

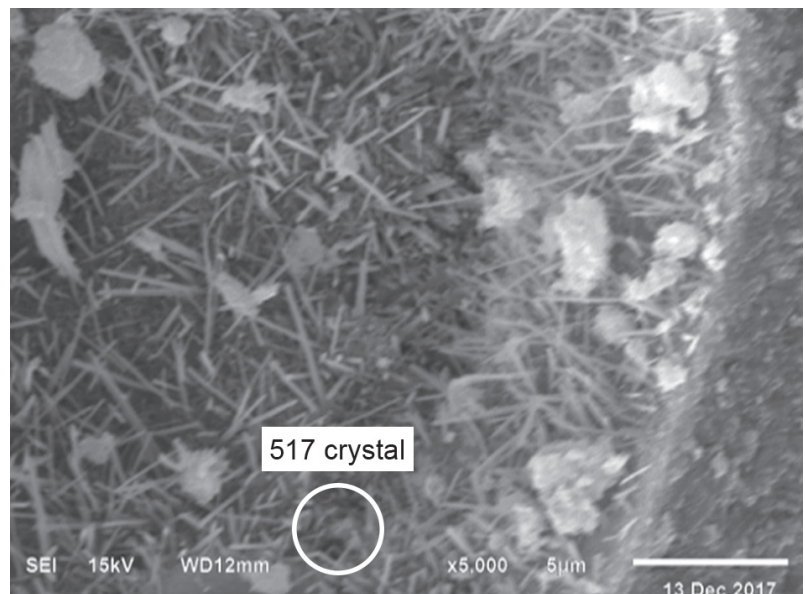

a) $50-\mathrm{P}$
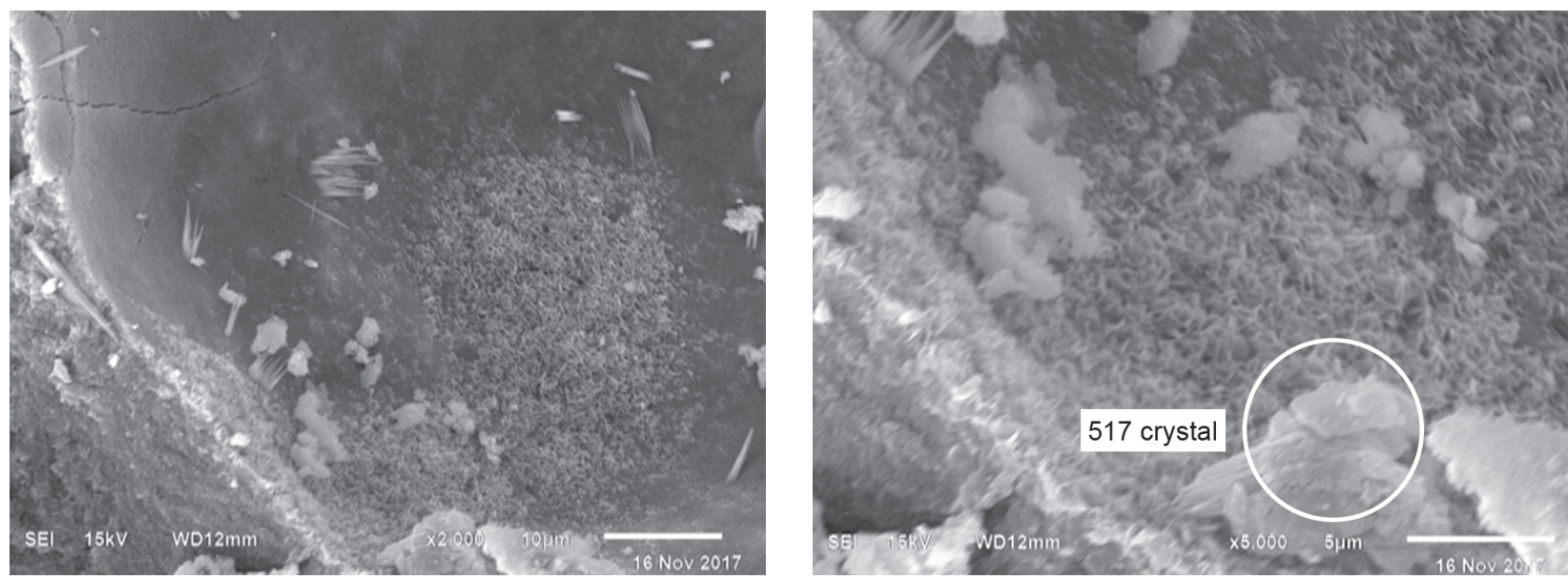

b) $50-\mathrm{N}$
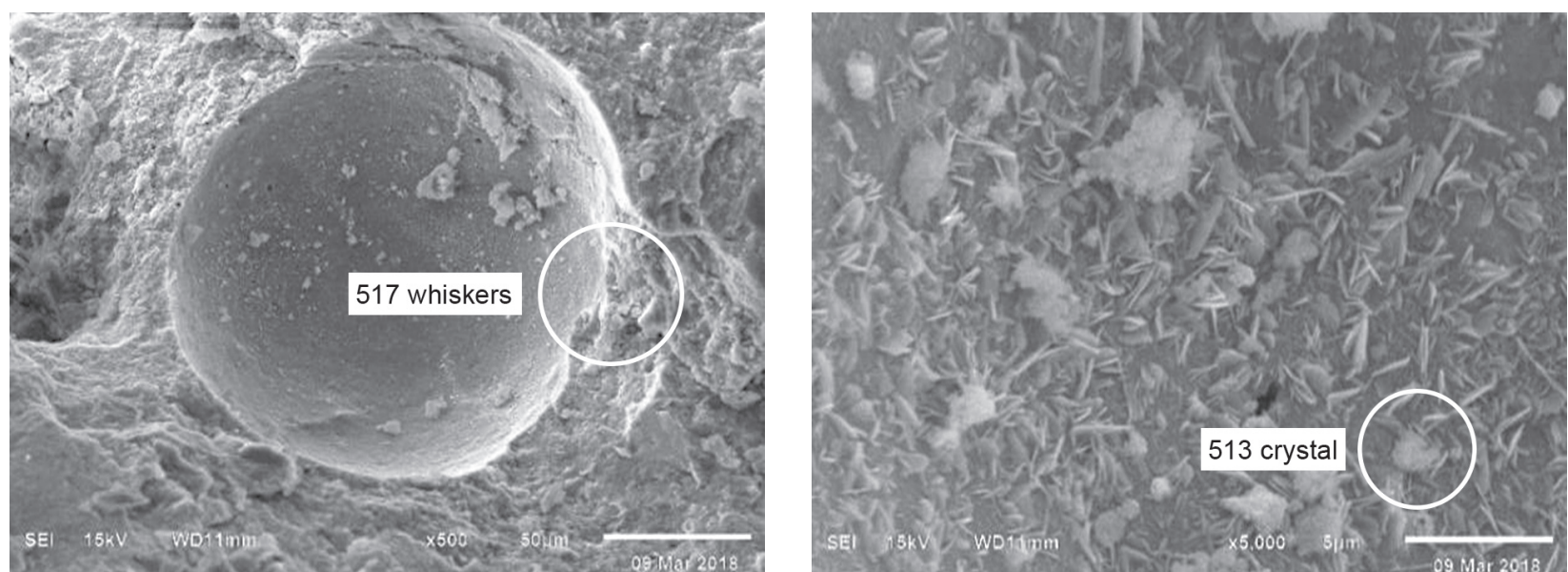

c) $80-\mathrm{N}$

Figure 6. The SEM images of GRBMS at $1 \mathrm{~d}$ and $28 \mathrm{~d}$ under $80^{\circ} \mathrm{C}$ and $50^{\circ} \mathrm{C}$. (Continue on next page)

Ceramics - Silikáty 63 (1) 32-44 (2019) 

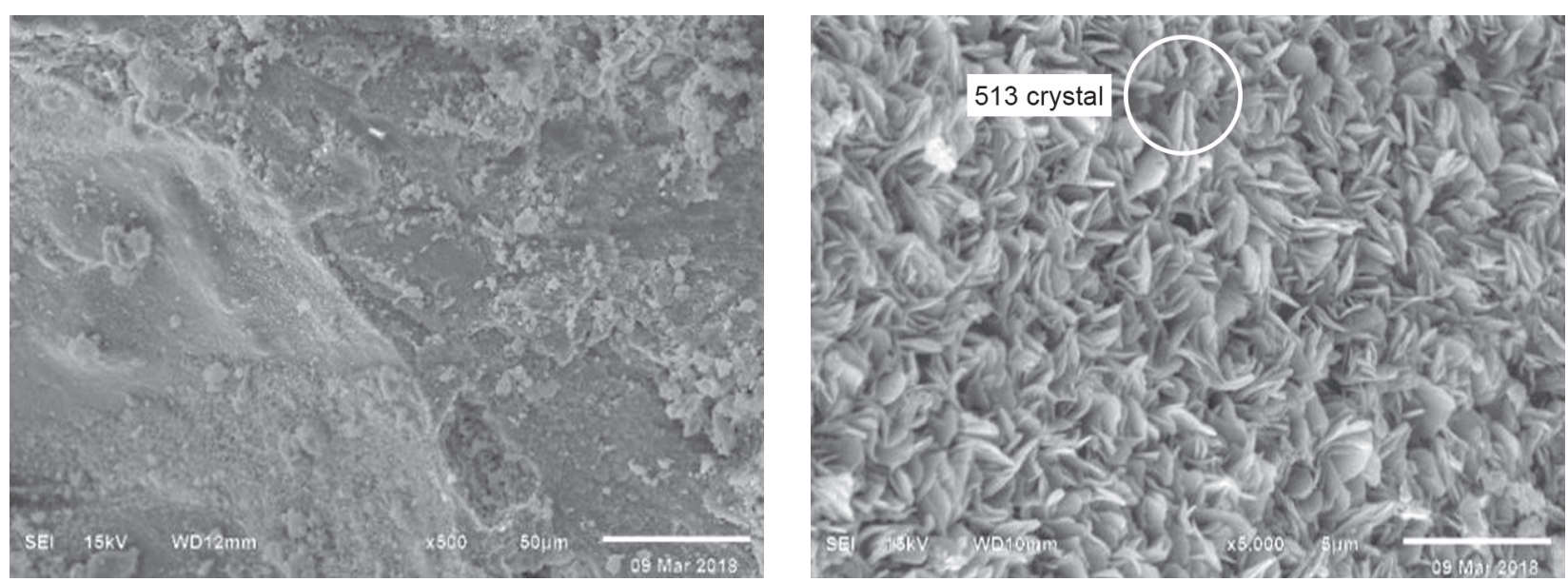

d) $80-\mathrm{N}$

Figure 6. The SEM images of GRBMS at $1 \mathrm{~d}$ and $28 \mathrm{~d}$ under $80^{\circ} \mathrm{C}$ and $50^{\circ} \mathrm{C}$.

These are acicular structures of the 517 phase resulting from the high temperature during the dehydration that are slowly separating from the middle of the whisker to form short and thick crystals. As the hydration process progresses, some short and coarse crystals slowly form a small piece-like structure. The SEM image of the GRBMS sample cured in the mould at a high temperature is shown in Figure 6d. A large number of interlaced, half-moon-like structures appears in the pores of the matrix of the composite. The sheet-like structures are identified as 513 crystals; they are close to each other and contain holes, resulting in an increase in the late strength. The different curing methods not only change the phases of the hydration product but also the microscopic morphology of the crystal, resulting in different performances of the hydration process. This result is consistent with previous research [26].

\section{Water resistance}

The flexural strength of the GRBMS-based composites cured for $28 \mathrm{~d}$ and subjected to prolonged water immersion is shown in Figure 7. The results indicate that specimen $80-\mathrm{P}$ is the most susceptible to

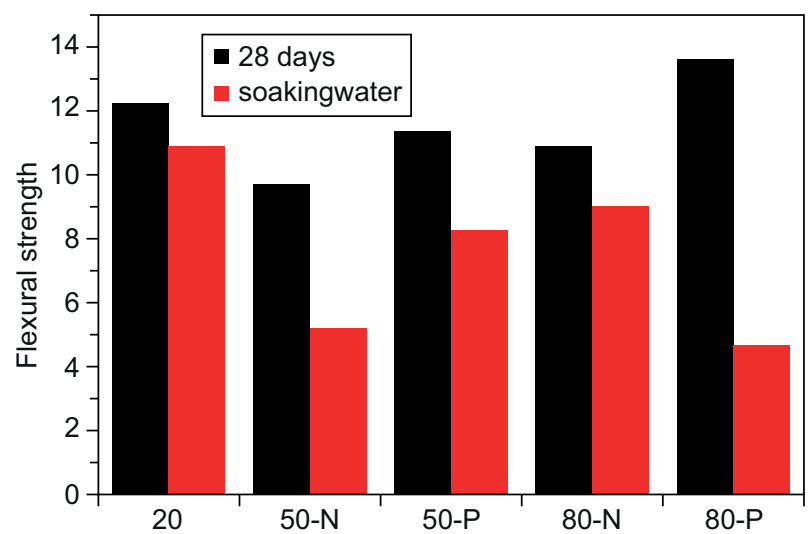

Figure 7. The flexural strength of the GRBMS cement-based composites for $28 \mathrm{~d}$ and the prolonged water immersions. water; after one month of soaking, the bending strength decreases from 13.61 $\mathrm{MPa}$ to 4.65 MPa. Unlike 80-P, $80-\mathrm{N}$ has good water resistance and its flexural strength is reduced from 10.89 MPa to 9.01 MPa. However, T(50) has an obvious contrast. Compared with the specimens cured at high temperature, the flexural strength of the GRBMS-based composites cured at $20{ }^{\circ} \mathrm{C}$ is stable and is $12.24 \mathrm{MPa}$ for $28-\mathrm{d}$ curing and $10.89 \mathrm{MPa}$ after water immersion.

The residual compressive strength and water resistance coefficients (Rw) of the GRBMS-based composites after prolonged water immersions are shown in Figure 8. Similarly, the 80-P specimen had the lowest compressive strength. The residual compressive strength and $\mathrm{Rw}$ of 80-P after 1 month of water immersion are only $11.2 \mathrm{MPa}$ and 0.26 , respectively. In addition, there was no significant difference in the Rw between 50-P and $80-\mathrm{N}$, indicating that the water resistance of the GRBMS specimens is affected by the curing temperature and curing conditions.

The XRD patterns of the GRBMS-based composites using five curing regimes at $28 \mathrm{~d}$ and after prolonged water immersions are shown in Figure 9. At $20^{\circ} \mathrm{C}$, the

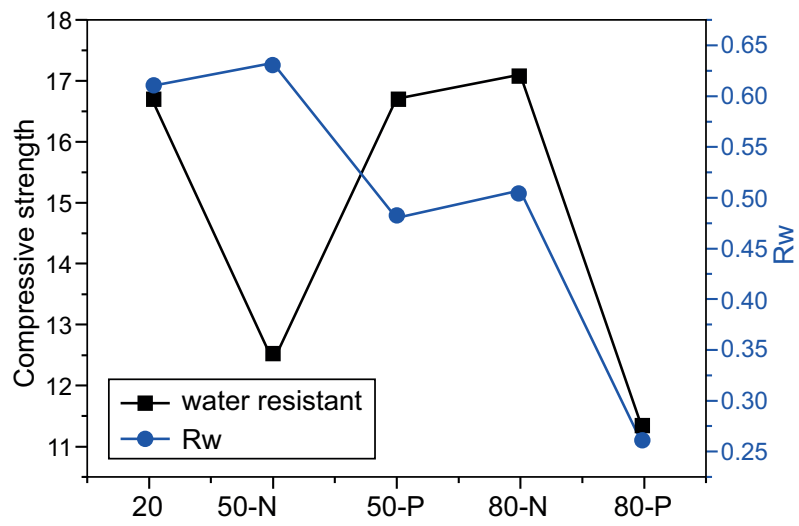

Figure 8. The remaining compressive strengths and water resistance coefficients $(\mathrm{Rw})$ of the GRBMS cement-based composites after prolonged water immersions. 


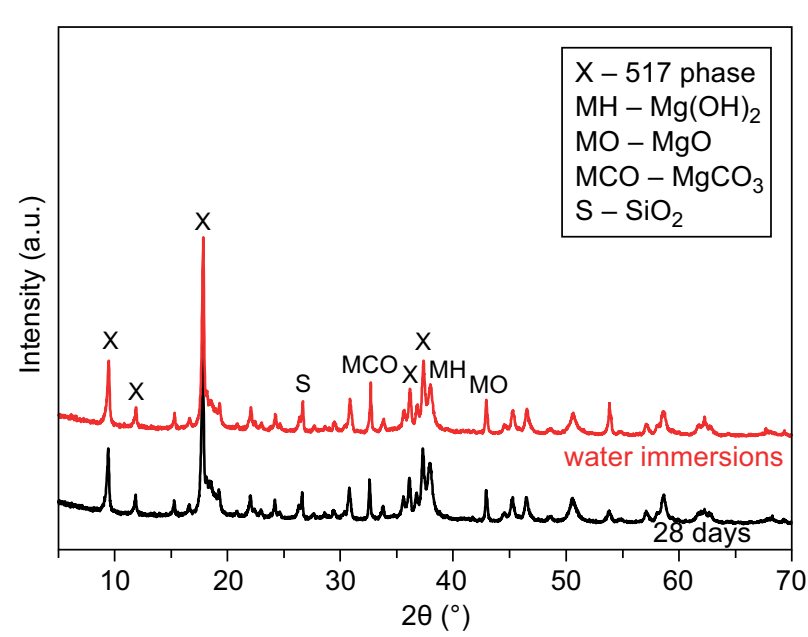

a) 20

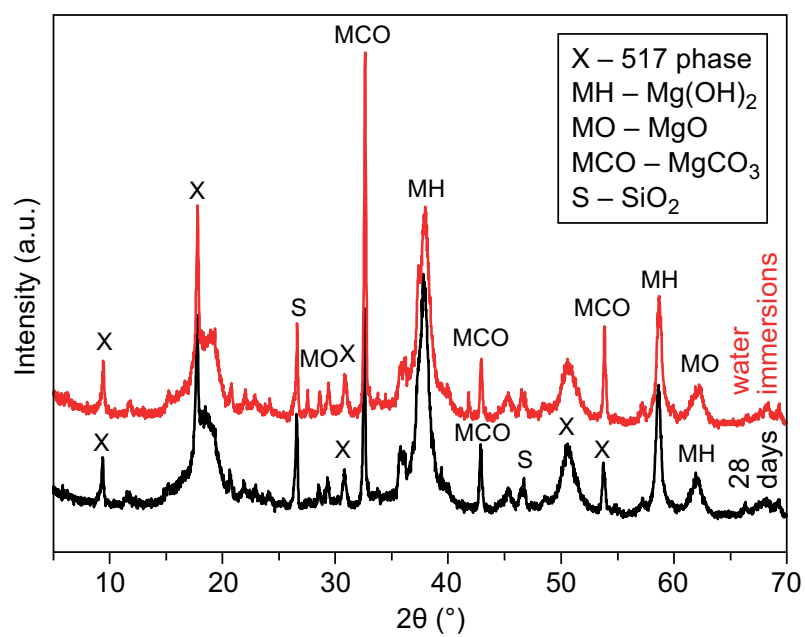

b) $50-\mathrm{P}$

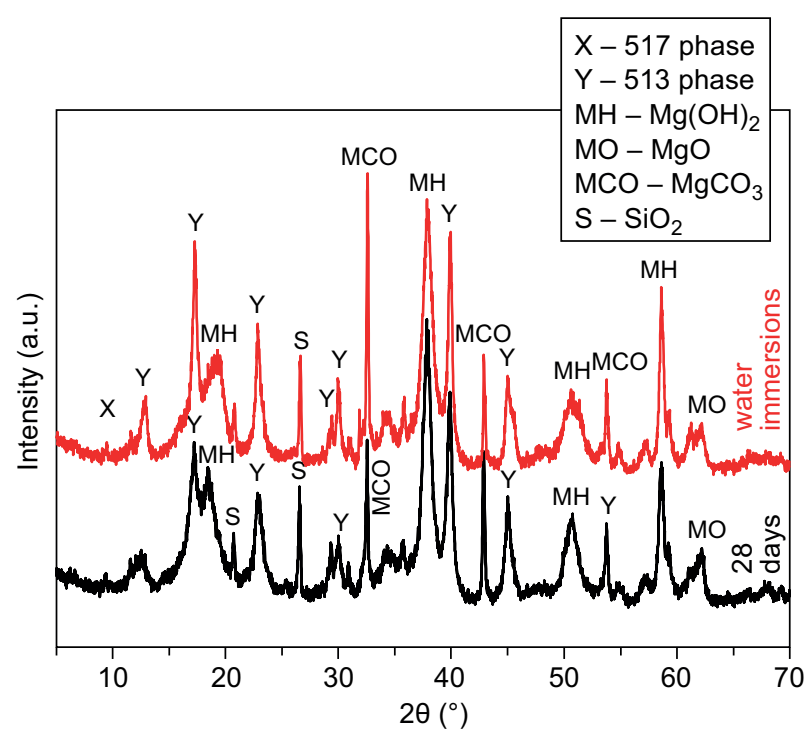

d) $80-\mathrm{P}$ phase of the water exhibits no differences between curing for $28 \mathrm{~d}$ and prolonged water immersion and the strength is lowered. The most likely cause is that the wood chips in the GRBMS absorbed the water, causing the matrix to be in a saturated or supersaturated state; this increased the volume and created expansion stress. At $50{ }^{\circ} \mathrm{C}$ for the two curing methods, the 517 phase diffraction peak of the $50-\mathrm{N}$ decreased significantly after prolonged water immersion, which may be one of the reasons for the differences in intensity between $50-\mathrm{N}$ and $50-\mathrm{P}$. The characteristic peak of the unreacted $\mathrm{MgO}$ in the matrix gradually decreases with an increase in the curing period, which indicates that the chemical reaction in the matrix continues during water immersion. It is observed from the XRD pattern before and after soaking that the phase of the material does not change significantly in the 80-P

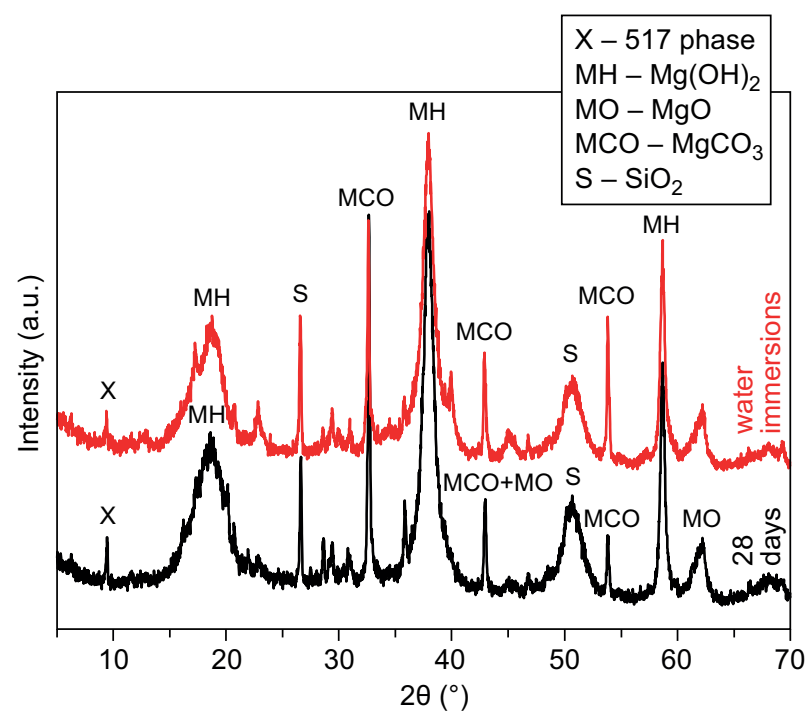

c) $50-\mathrm{N}$

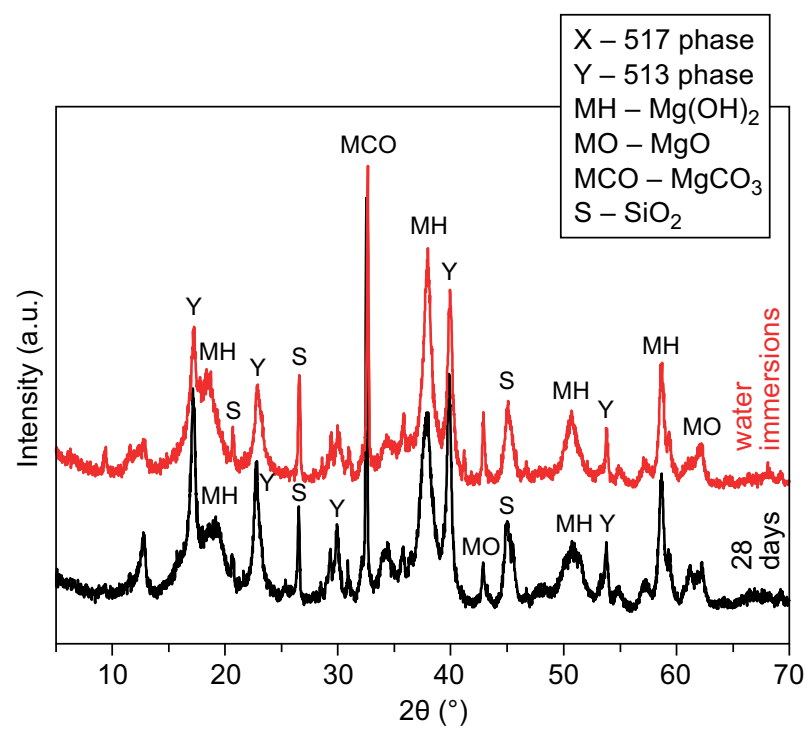

e) $80-\mathrm{N}$

Figure 9. The XRD patterns of the GRBMS cement-based composites using five curing regimes at $28 \mathrm{~d}$ and after the prolonged water immersions. 
Liu P., Wu Ch., Luo K., Chen C., Chen Y., Zhang H., Yu H.

specimen. These results, as well as the results shown in Figures 7 and 8 indicate that $80-\mathrm{P}$ is most affected by water; the most likely cause is the early high-temperature curing, which results in the rapid volatilisation of the free water in the cement matrix at a high temperature, forming many large and small pores. When the $80-\mathrm{P}$ specimen is

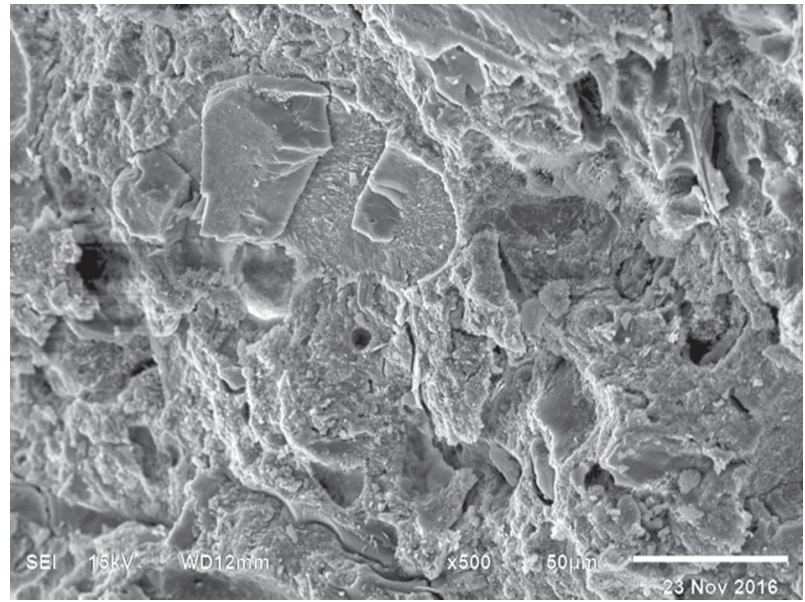

a) 20

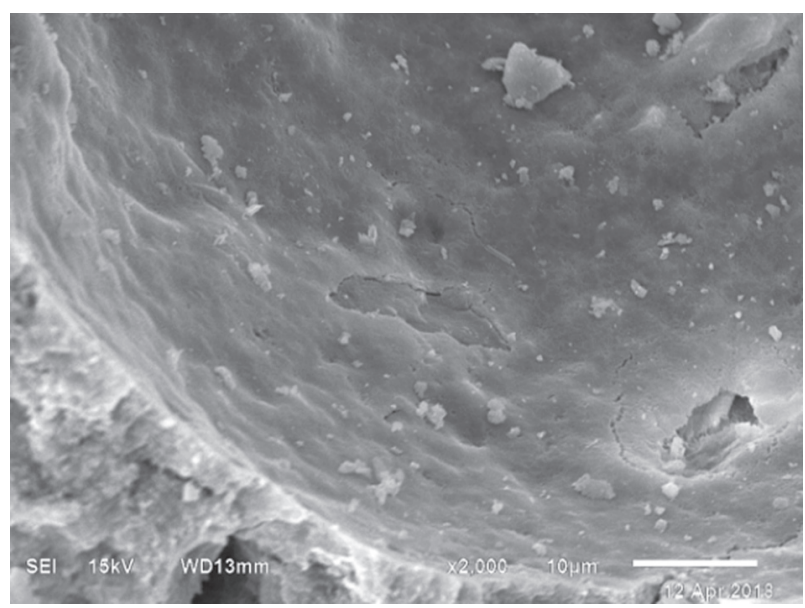

c) $50-\mathrm{N}$

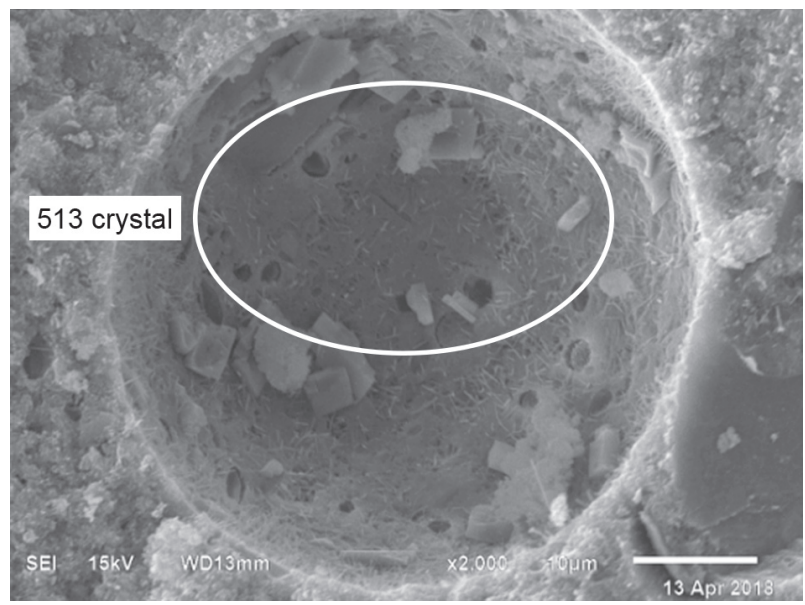

e) $80-\mathrm{N}(\times 2000)$ soaked for a period of time, the external moisture fills the pores in the matrix; in addition, the wood chips in the high-temperature solidified cement matrix are easily saturated with water, resulting in a rapid increase in the volume of the $80-\mathrm{P}$ specimen and a more pronounced decrease in the strength.

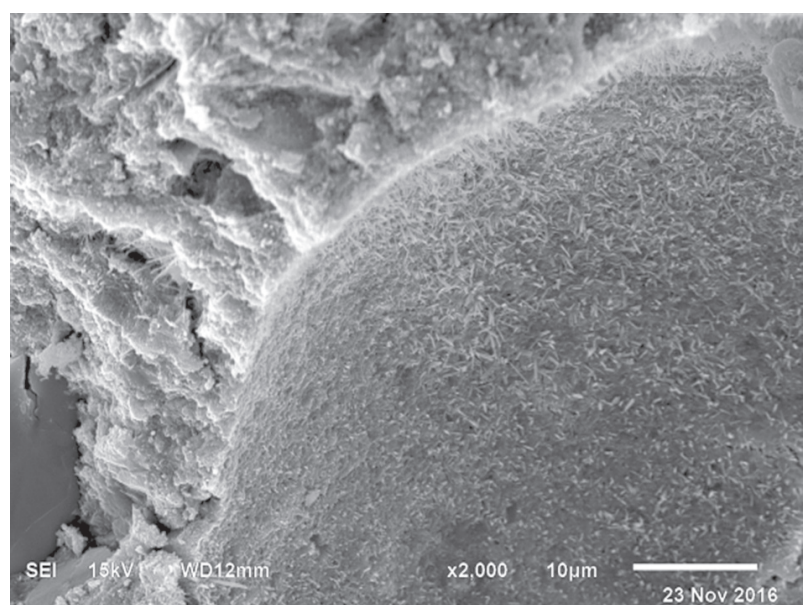

b) 20

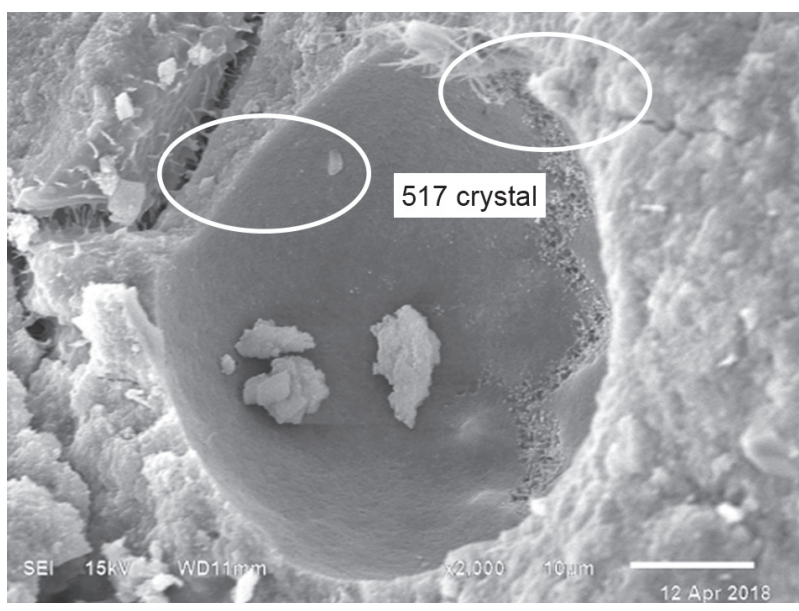

d) $50-\mathrm{P}$

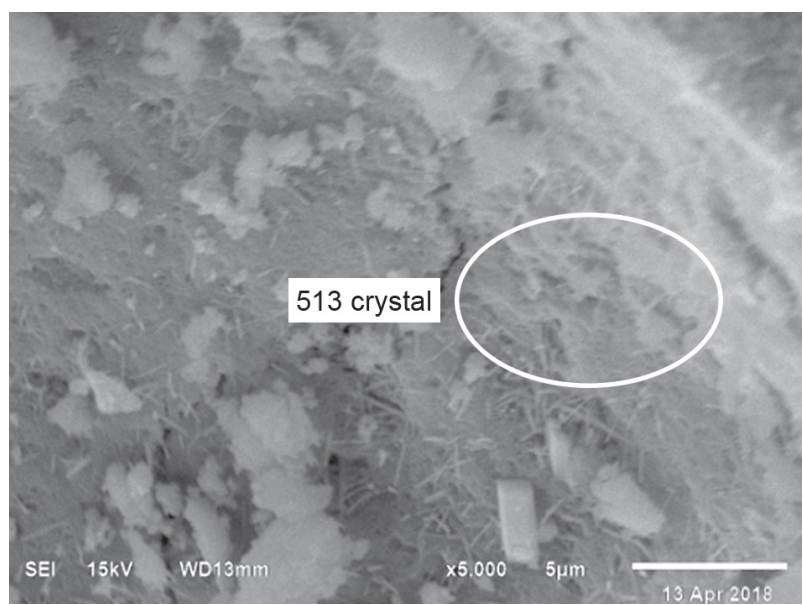

f) $80-\mathrm{N}(\times 5000)$

Figure 10. The SEM morphologies of the paste matrices of the MOC cement-based composites at 28 days under the adopted four curing regimes. (Continue on next page) 


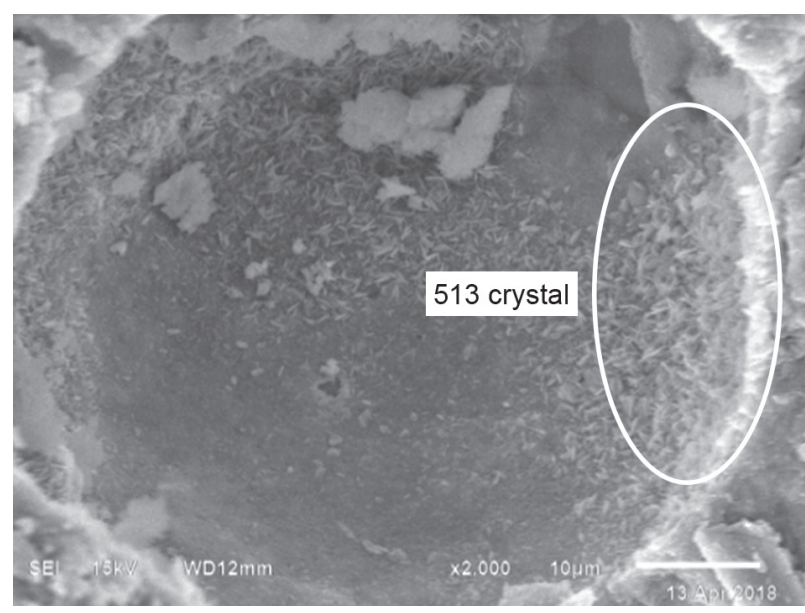

g) $80-\mathrm{P}(\times 2000)$

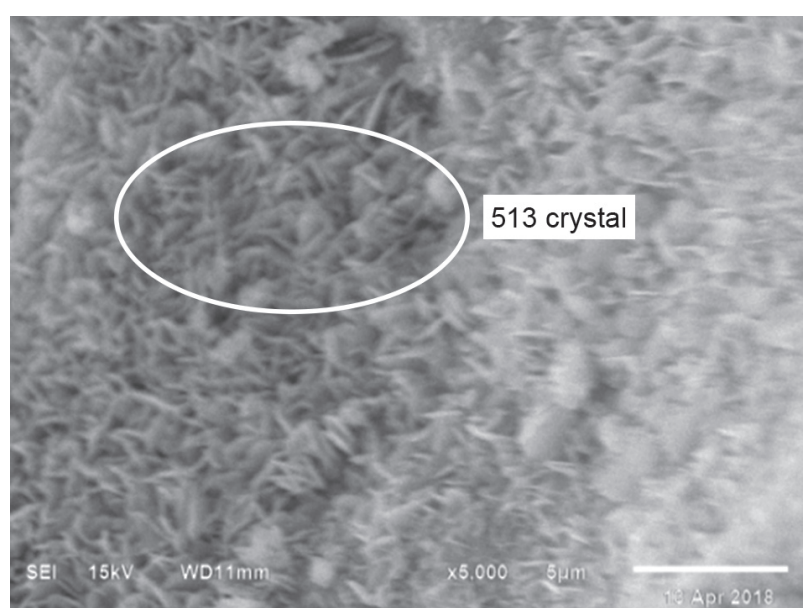

h) $80-\mathrm{P}(\times 5000)$

Figure 10. The SEM morphologies of the paste matrices of the MOC cement-based composites at 28 days under the adopted four curing regimes.

The microstructure of the composite matrix after immersion is shown in Figure 10. Compared with the SEM image of the specimen cured for $28 \mathrm{~d}$ shown in Figure 5, it is observed that the morphology of the 517 crystal in the pores after water immersion still exhibits a needle-like structure, but the cement matrix is thicker, which is mainly due to the water absorption by the cement composite. Comparing the SEM morphology shown in Figure 6, the microstructure changes before and after water immersion can be proposed. Compared to the results shown in Figure 6, Figure 10 shows that the GRBMS matrix of $80-\mathrm{N}$ contains more 513 phases and its morphology has changed from a sheet-like structure to a fibre-like structure. Most of the 80-P specimen contains 513 phases with a sheet-like structure. Some of the short fibres in the hydration product have disappeared after water immersion. The microstructure is less compact due to the erosion effect of the water. In summary, the observed morphology explains the poor water resistance of the 80-P specimen. This may indicate that hightemperature curing and different curing conditions change the normal crystal habit of the 5-phase crystals, making them more susceptible to the effects of water and resulting in lower water resistance.

\section{CONCLUSION}

In this study, the effects of different curing conditions on the performance of GRBMS were investigated. The following conclusions are drawn:

- The curing temperature during the early curing period has an important effect on the primary reaction products of the GRBMS. The main strength phase resulting from curing temperatures of $20{ }^{\circ} \mathrm{C}$ and $50{ }^{\circ} \mathrm{C}$ is the needle-like 517 phase, whereas the main strength phase resulting from the curing temperature of $80^{\circ} \mathrm{C}$ is the flaky 513 phase.
The strength phase of the 80-P cement-based material cured at $200 \mathrm{C}$ for $1 \mathrm{~d}$ is the 517 phase. After hightemperature curing for $3 \mathrm{~d}$, the 517 phase loses water and changes into the 513 phase, resulting in morphology changes and increases in the strength.

- The SEM results show that at high-temperature curing, the curing mode changes the microscopic morphology of the hydration product and causes differences in the hydration performance.

- The water resistance was lowest for the $80{ }^{\circ} \mathrm{C}$ precuring specimen because of many pores in the cement matrix, the absorption of water by the wood chips, and the resulting volume expansion. There was no significant difference in water resistance between the specimens cured at $50{ }^{\circ} \mathrm{C}$ pre-curing and those cured directly and at a high temperature of $80{ }^{\circ} \mathrm{C}$. This indicates that the water resistance of the GRBMS specimens is affected by the curing temperature and the curing mode.

Future work will be focused on the influence of the curing temperature on the intensity of phase hydration of the GRBMS specimens. This can be achieved by creating 517 phase seed crystals using ball milling and filtration methods. The internal structure of the 517 phase seeds will be compared with the case of natural curing.

\section{Acknowledgement}

This study was supported by the National Natural Science Foundations of China (Grants no. 51662035) and the Science and Key $R \& D$ and transformation planned project of Qinghai province (Grants no. 51662035 and no. 2019-NN-159) and building energy-saving materials and engineering safety technology innovation service platform (Grants no. 2018-0401-ZJC-0004) and the teaching team of civil engineering safety technology of Qinghai University (Grants no. TD1804). 


\section{REFERENCES}

1. Demediuk T., Cole W. F., Hueber H. V. (1955): Studies on magnesium and calcium oxychlorides. Australian Journal of Chemistry, 8,215-233. doi:10.1071/CH9550215

2. Xiang L., Liu F., Li J., Jin Y. (2004): Hydrothermal formation and characterization of magnesium oxysulfate whiskers. Materials Chemistry and Physics, 87, 424-429. doi:10.1016/j.matchemphys.06.021.

3. Beaudoin J.J., Ramachandran V.S. (1978): Strength development in magnesium oxysulfate cement. Cement and Concrete Research, 8, 532-536. doi:10.1016/0008-8846 (78)90063-7

4. Shand M.A., Hoboken N.J. (2006). The chemistry and technology of magnesia. John Wiley and Inc, pp.231-241.

5. Zhong G. L., Zhen Y. Y., Quan J. L., Zi Y. W., Shi H.L. (2003): Experimental study on urban refuse/magnesium oxychloride cement compound floor tile. Cement and Concrete Research, 33, 1663-1668. doi:10.1016/S00088846(03)00136-4.

6. Ellis H. (1986): Fire Barrier Coating Composition Containing Magnesium Oxychlorides and High Alumina Calcium Aluminate Cements or Magnesium Oxysulphate. U. S. Patent, 4,572-862.

7. Hoshino S., Tanaka H., Kimura T. (1983). Fibrous magnesium oxysulfate as a new reinforcement for plastics. in: Proceedings of the Annual Technical Conference of Society of Plastics Engineers. Tokyo, pp. 318-321.

8. You C.W., Fa H.Y., Fang H.Z., Mei J.D., Jin W., Shan Y.T. (2015): Effects of phosphoric acid and phosphates on magnesium oxysulfate cement. Materials and Structures, 48, 907-917. doi:10.1617/s11527-013-0202-6.

9. Cole W.F., Demediuk T. (1955): X-Ray, thermal, and Dehydration studies on Magnesium oxychlorides. Australian Journal of Chemistry, 8, 234-251.doi:10.1071/CH9550234

10. Demediuk T and Cole W.F. (1957): A study of magnesium oxysulphates. Australian Journal of Chemistry, 10, 287-294. doi:10.1071/CH9570287

11. Urwong Land Sorrell C.A. (1980): Phase relations in magnesium oxysulfate cements. Journal of the American Ceramic Society, 63, 523-526, doi:10.1111/j.1151-2916. 1980.tb10757.x.

12. Kahle K. (1972): Mechanism of formation of magnesium sulphate cement. Silikattecnic, 23, 148-151.

13. Vincenzo M.S. (2011): Influence of curing temperature on the evolution of magnesium oxychloride cement. Journal of Materials Science, 46, 6726-6733. doi:10.1007/s10853011-5628-z.

14. Chengyou W., Hongfa Y., Huifang Z., Jinmei D., Jing W., Yongsan T. (2013): Effects of phosphoric acid and phosphates on magnesium oxysulfate cement. Materials and Structures, 10,1-11. doi:10.1617/s11527-013-0202-6.

15. Li Z. J., Chau C. K. (2007): Influence of Molar Ratios on Properties of Magnesium Oxychloride Cement. Cement and
Concrete Research, 37, 866-870. doi:10.1016/j.cemconres. 2007.03.015.

16. Karimi Y., Monshi A. (2011): Effect of magnesium chloride concentrations on the properties of magnesium oxychloride cement for nano $\mathrm{SiC}$ composite purposes. Ceramics International, 37, 2405-2410. doi:10.1016/j.ceramint.2011. 05.082 .

17. Sglavo V. M., De Genua F., Conci A., Ceccato R., Cavallini R. (2011): Influence of curing temperature on the evolution of magnesium oxychloride cement. Journal of Materials Science, 46, 6726-6733, doi:10.1007/s10853-011-5628-z.

18. Silva R.V., Brito J., Saikia. (2013): Influence of curing conditions on the durability-related performance of concrete made with selected plastic waste aggregates. Cement and Concrete Composites, 35, 23-31. doi:10.1016/j.cemconcomp.2012.08.017.

19. Blom J., Rahier H., Wastiels J. (2014): Effect of curing conditions on the dimensional and thermal stability of calcium phosphate cement for elevated temperature applications. Cement and Concrete Research, 66, 102-109. doi:10.1016/j.cemconres.2014.07.019.

20. Hongfa Y., Jinmei D. (2012): Accelerated life test and microscopic mechanism of high performance glass fiber reinforced magnesium oxychloride cement. Bulletin of the Chinese Ceramic Society, 31, 111-116. doi:10.16552/j.cnki. issn1001-1625.2012.01.023

21. Qianqian L., Hongfa Y. (2010): Durability and degradation mechanism of glass fiber reinforced magnesium oxychloride cement. Bulletin of the Chinese Ceramic Society, 29, 908-913. Doi:10.16552/j.crki.issn1001-1625.2010.04.046.

22. Dong J. M., Yu H. F., Zhang L. M. (2010): Study on experimental conditions of hydration methods of determining active magnesium oxide content. Journal of Salt Lake Research, 18(1), 38-41.

23. Birchal V.S.S., Rocha S.D.F., Ciminelli V.S.T. (2000): The effect of magnesite calcination conditions on magnesia hydration. Minerals Engineering, 13, 1629-1633. doi:10.1016/ S0892-6875(00)00146-1.

24. Zongjin L., Chau C. K. (2008): Reactivity and function of magnesium oxide in Sorel cement. Journal of Materials in Civil Engineering, 20, 239-244. doi:10.1061/(ASCE)08991561(2008)20:3(239)

25. Wen J., Yu H., Li Y., Wu C., Dong J. (2014): Effects of citric acid on hydration process and mechanical properties of thermal decomposed magnesium oxychloride cement. Journal of Wuhan University of Technology-Mater. Sci. Ed., 29(1), 114-118. doi:10.1007/s11595-014-0877-8

26. Biwan X., Hongyan M., Chuanlin H., Shuqing Y., Zongjin L. (2016 ): Influence of curing regimes on mechanical properties of magnesium oxychloride cement-based composites. Construction and Building Materials, 102, 613-619. doi:10.1016/j.conbuildmat.2015.10.205

27. Luo J., Yao J.(1998) :Study on kinetics of hydration for $\mathrm{MgO}-\mathrm{MgSO}_{4}-\mathrm{H}_{2} \mathrm{O}$ cementitious system. Journal of the Chinese Ceramic Society, 26, 157-163 